\title{
19.
}

136

\section{High-dose chemotherapy regimens for solid tumors}

\author{
E. van der Wallt, J. H. Beijnen* and S. Rodenhuis \\ Department of Medical Oncology, The Netherlands Cancer Institute, \\ Plesmanlaan 121, 1066 CX Amsterdam, The Netherlands \\ *also: Department of Pharmacy, Slotervaart Hospital, Louwesweg 6, \\ 1066 EC Amsterdam, The Netherlands
}

\begin{abstract}
High-dose chemotherapy with blood progenitor cell transplantation is increasingly recognized as a potentially valuable treatment for breast cancer, germ cell cancer, ovarian cancer and other solid tumors. A variety of cytotoxic drugs, particularly alkylating agents, have been investigated either alone or in combinations. Current, predominantly small, phase I and phase II clinical trials to not adequately compare the efficacy of these regiments and patterns of dose-limiting extramedullary toxicity are emerging. Busulfan, carmustine (BCNU) and mitomycin $\mathrm{C}$ cause veno-occlusive disease (VOD) of the liver in some patients and the latter two agents also cause interstitial pneumonitis. Cisplatin and ifosfamide only allow minor dose escalation before renal failure becomes prohibitive. Cyclophosphamide, thiotepa, melphalan and etoposide allow substantial dose escalation above standard and are mainly associated with mucositis. Moderate dose escalations of mitoxantrone and carboplatin are possible, limited by cardiotoxicity and neurotoxicity, respectively. Advances in supportive care have abolished bone marrow suppression as the dose-limiting toxicity in chemotherapy. Severe and potentially fatal extramedullary toxicity following high-dose chemotherapy can only be avoided by administering agents with predictable toxicity patterns and by carefully considering their clinical pharmacology.
\end{abstract}

\section{Introduction}

High-dose chemotherapy with autologous blood stem cell support is increasingly recognized as a potentially valuable treatment in the management of solid tumors. The situation in some chemosensitive solid tumors, such as relapsing germ cell

Correspondence should be addressed to: S. Rodenhuis, M. D., Dept of Medical Oncology, The Netherlands Cancer Institute, Plesmanlaan 121, 1066 CX Amsterdam, The Netherlands.

tPresent address: Department of Oncology, Free University Hospital, De Boelelaau 1117, $1081 \mathrm{HV}$, Amsterdam, The Netherlands 
cancer or childhood neuroblastoma, resembles the state of affairs of a few years ago in non-Hodgkin's lymphoma. Anecdotal evidence and studies employing historical control groups have suggested the superiority of high-dose chemotherapy over standard-dosed treatment, but randomized studies are lacking. Non-randomized studies $(1,2,3)$ indicate efficacy in the adjuvant treatment of high-risk breast cancer and data from the American and European Bone Marrow Transplantation Registries $(4,5)$ suggest that a specific group of patients with advanced breast cancer may achieve long-term disease-free survival after high-dose chemotherapy. Results in ovarian cancer and in small-cell lung cancer may be viewed as 'encouraging' but are essentially inconclusive (6).

Recent advances in supportive care have significantly contributed to the feasibility of high-dose chemotherapy. Hematopoietic growth factors and peripheral blood progenitor cell transplantation have led to a marked reduction in the duration of the aplastic period following high-dose chemotherapy. With the in vitro expansion of hematopoietic progenitor cells on the horizon, cancer chemotherapy is entering a new era when myelosuppression is no longer the dose-limiting toxicity. Inevitably, damage to other tissues and organs is becoming more pronounced. It is this frequently irreversible or even lethal organ toxicity that must be dealt with if further dose intensification is to be achieved.

There are currently two approaches to prevent severe extramedullary toxicity in patients exposed to high-dose chemotherapy. The first is to prevent overdosing, which can be achieved by carefully considering the pharmacology of the agents to be employed and to correct for renal function of hepatic abnormalities or even to apply a test-dose to predetermine pharmacokinetic parameters. Another approach is to avoid drugs or combinations of drugs that are known to be associated with excess toxicity. Careful consideration of the mechanisms of action, pharmacokinetics and toxicity profiles of the different agents to be used is therefore imperative.

In the absence of meaningful efficacy evaluations, the frequency and prevention of severe organ toxicity is a critical consideration in the selection of high-dose regimens for clinical studies.

\section{Single agents in high-dose therapy}

The cytotoxic agents most frequently used in the autotransplant setting for solid tumors will be discussed separately. An overview of the pharmacokinetics and toxicity of each drug as used in high-dose chemotherapy regimens will be given (Table 1).

\section{Cyclophosphamide}

Cyclophosphamide belongs to the group of oxazaphosphorines, which are derivatives of nitrogen mustard. Cyclophosphamide is a pro-drug and requires hydroxylation by hepatic cytochromes $\mathrm{P} 450$ to exert its cytotoxic activity. 4-Hydroxycyclophosphamide and its tautomer, aldophosphamide, yield the strong alkylating agent phosphoramide mustard after elimination of acrolein $(7,8)$. Cytotoxicity is believed to occur by the formation of crosslinks between DNA strands. 


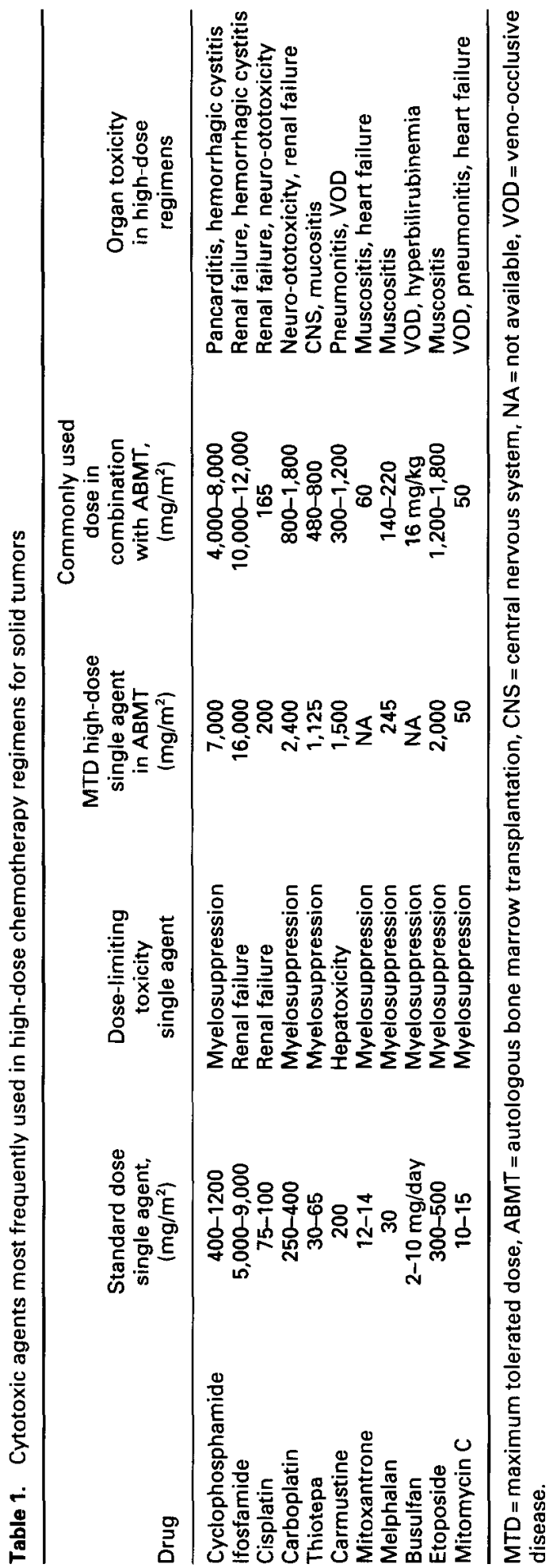


Acrolein itself is devoid of cytotoxic properties. It is excreted in the urine and is the major cause of hemorrhagic cystitis associated with cyclophosphamide therapy (9).

\section{Pharmacokinetics and toxicity}

Cyclophosphamide metabolism exhibits autoinduction as shown by a decrease in plasma half-life following repetitive intravenous (IV) administration $(7,11,12)$, with mean plasma half-lives of $8.7 \pm 4.6 \mathrm{~h}$ (range 4.4-25.0) and $3.6 \pm 0.9 \mathrm{~h}$ (range 1.7-6.0) after two consecutive doses of $60 \mathrm{mg} / \mathrm{kg}$ of cyclophosphamide, respectively (11). The area under the concentration-time curve (AUC) of the active metabolites remains, however, unchanged under these conditions explaining why the therapeutic and toxic effects of cyclophosphamide are not influenced by the autoinduction phenomenon (7). Elimination occurs mainly by hepatic metabolism and approximately $10 \%$ is excreted unchanged into the urine $(13,14)$. Dose adjustment of cyclophosphamide is not required in the presence of liver or renal dysfunction (15).

The maximum tolerated dose (MTD) of cyclophosphamide, without bone marrow support, has been reported to be $7 \mathrm{~g} / \mathrm{m}^{2}$, the dose-limiting toxicity being myelosuppression (10). In high-dose chemotherapy regimens with autologous bone marrow support, the dose-limiting toxicity of cyclophosphamide is cardiotoxicity. In doses over $1.55 \mathrm{~g} / \mathrm{m}^{2}$ per day, cyclophosphamide-associated cardiotoxicity has been reported in $25 \%$ of patients (16). Endothelial damage may occur inducing myocardial necrosis which can cause severe and often refractory congestive heart failure. This usually occurs 1-10 days after the first dose of cyclophosphamide (16).

Hemorrhagic cystitis, due to the hepatic metabolite acrolein, has been observed in 12 to $35 \%$ patients following high-dose cyclophosphamide therapy (17). Simultaneous administration of sodium-2-mercapto-ethane sulphonate (mesna) is widely used and prevents the occurrence of hemorrhagic cystitis. Forced hydration, urinary alkalinization and bladder irrigation have also been used, alone or in combination, but the optimal combination for the prevention of cyclophosphamideinduced hemorrhagic cystitis is, however, still a matter of debate $(17,18)$.

In addition, a transient but direct toxic effect of cyclophosphamide on the renal tubules has been described which may mimic the syndrome of inappropriate antidiuretic hormone secretion (19).

\section{Ifosfamide}

Ifosfamide is an oxazaphosphorine, which, like its analog cyclophosphamide, requires biotransformation in order to become cytotoxic (20). Ifosfamide is activated through hydroxylation by the hepatic cytochrome P-450 mixed function oxidases yielding 4-hydroxy-ifosfamide, a potent alkylating agent in vitro, with a steep linear log dose-response curve (21).

4-Hydroxyifosfamide is in equilibrium with its tautomer aldoifosfamide. Both can be inactivated either by oxidation with aldehyde dehydrogenase or produce the cytotoxic alkylating species ifosforamide mustard by elimination of acrolein (20). When compared with cyclophosphamide metabolism, the rate of ring hydroxylation is reduced by the presence of the ring $\mathrm{N}$-chloroethyl group in the ifosfamide molecule. Consequently, oxidation to inactive metabolites is a more important 
metabolic pathway for ifosfamide (20). As a result, serum concentrations of the activated ifosfamide species are lower than those of activated cyclophosphamide, measured after the same dose of the parent drug. This explains the difference in dose between cyclophosphamide and ifosfamide that is required to obtain equitoxic alkylating effects; for this purpose, the dose of ifosfamide must be 3 to 4 times higher than that for cyclophosphamide $(20,22)$.

Ifosforamide mustard induces cytotoxicity by DNA crosslinking. Based on studies in animals, ifosfamide has been reported to be more active and less toxic than cyclophosphamide with an improved therapeutic/toxic ratio achieved with a fractionated dose schedule (22).

Pharmacokinetics and toxicity. The pharmacokinetic parameters of ifosfamide exhibit large inter- and intrapatient variability, suggested to arise mainly from genetic factors (20).

Ifosfamide is commonly administered intravenously. Fractionated dose schedules are used which allow for an increase of the total dose by nearly $50 \%$ (23). The mean elimination half-life is $6 \mathrm{~h}$ and may be prolonged in obese individuals. Similar to cyclophosphamide, ifosfamide induces its own metabolism as shown in a decreased elimination half-life and an increased total body clearance following repeated daily administrations (20). Less than $20 \%$ of ifosfamide is bound to plasma proteins. The concentration of the active compound 4-hydroxyifosfamide detected in cerebrospinal fluid (CSF) is about $15 \%$ of that measured in the plasma. Between 2.5 and $50 \%$ of the administered dose is excreted unchanged in the urine (20).

Animal studies and phase I and II studies in various solid tumors have suggested a lack of cross-resistance between ifosfamide and cyclophosphamide (24-26).

The dose-limiting toxicity of high-dose ifosfamide is renal failure, manifested by renal tubular acidosis. This has been observed at a dose of $18 \mathrm{~g} / \mathrm{m}^{2}$, given in divided doses over 4 days (22). At that dose level, hematological toxicity has not required autologous bone marrow support. However, due to renal toxicity, the maximum tolerated dose has been reported to be $16 \mathrm{~g} / \mathrm{m}^{2}$, provided that adequate uroprotection with mesna is performed. In the absence of mesna, hemorrhagic cystitis has been the dose-limiting toxicity, with an overall incidence of 18 to $40 \%$.

Neurotoxicity is dose-related and may be due to the presence of the metabolite chloroacetaldehyde. As with busulfan, decreased levels of glutathione, responsible for the detoxification of chloroacetaldehyde, could be the underlying mechanism (27). The symptoms are somnolence, hallucinations, confusion and disorientation and usually begin on day 4 of the administration. The symptoms continue for a median of 5 days. The reversible neurotoxicity of ifosfamide seems to occur more often in patients who also develop renal failure (22).

Pretreatment with doxorubicin may compound ifosfamide-related congestive heart failure. In contrast to cyclophosphamide, there is no reported cardiotoxicity of ifosfamide in other settings. Other dose-related toxicities reported include nausea, vomiting and mucositis.

\section{Cisplatin}

Cisplatin (cis-diammine-dichloroplatinum) is activated by hydrolysis to produce the highly reactive alkylating cis-diammine diaquated species. The hydrolysis rate is 
partially determined by the chloride concentration of the solubilizing media (28). The active compound exerts its cytotoxic effect through formation of inter- and intrastrand crosslinking of DNA (29). Cisplatin is active in all phases of the cell cycle, but it is most active in the G1-phase.

Pharmacokinetics and toxicity. Cisplatin is extensively and irreversibly bound to plasma proteins; the free-drug fraction is responsible for its pharmacological activity (30). The initial plasma half-life of free cisplatin ( $5 \%$ of total platinum) is about $30 \mathrm{~min}$; the terminal half-life is considerably longer, greater than $24 \mathrm{~h}$ (31). Cisplatin is eliminated by renal filtration, tubular secretion and tissue alkylation (28).

Nephrotoxicity is prominent, prohibiting dose escalation of cisplatin above $200 \mathrm{mg} / \mathrm{m}^{2}$. Acute renal failure is related to the peak plasma concentration and its duration, and is more frequent in the presence of a decreased glomerular filtration rate (29). Adequate and prolonged hydration with a urine flow above $200 \mathrm{ml} / \mathrm{h}$ is the mainstay of prophylactic treatment (28). Platinum is known to be present in renal tissue for up to 4 months following administration. This may eventually potentiate nephrotoxic effects of other agents, such as aminoglycoside antibiotics (32). Damage to the renal tubuli induces hypomagnesemia and hypokalemia (33).

Disabling peripheral neuropathy, manifested as numbness, pain and small motor dysfunction, which is only partially reversible, has been reported in $26 \%$ of patients receiving $200 \mathrm{mg} / \mathrm{m}^{2}$ cisplatin (34). Ototoxicity is irreversible and is more pronounced at high frequencies (35).

Myelosuppression is dose-related and characterized by a profound and prolonged granulocytopenia. A marked increase in platelets and red blood cell transfusion occurs when the dose of cisplatin is increased from 100 to $200 \mathrm{mg} / \mathrm{m}^{2}(34)$.

\section{Carboplatin}

Carboplatin is a second generation, platinum-containing compound. Carboplatin is metabolized to monoaquo and diaquo species, similar to the activation process of cisplatin although it is associated with a lower conversion rate (36). The generated electrophillic species are capable of a covalent binding to nucleophils such as proteins and DNA. It is assumed that the formation of intra- and interstrand DNA cross-links is responsible for the cytotoxicity of this compound (37).

Pharmacokinetics and toxicity. Carboplatin unlike cisplatin, is only $25 \%$ protein bound following IV administration. As a result, the AUC, expressed in $\mu \mathrm{mol} . \mathrm{min} / \mathrm{l}$, of the free drug is 15 to 17.5 times higher for carboplatin than for cisplatin (36). The pharmacokinetic profile of the free drug can be described with a biexponential equation with $t_{1 / 2} \alpha$ of 6-20 min and $a t_{1 / 2} \beta$ of 1.5 to $7.5 \mathrm{~h}$.

Glomerular filtration accounts mainly for the renal excretion of carboplatin and is the major route to elimination $(38,39)$. Active tubular secretion is irrelevant which, together with the minimal protein binding, explains why the creatinine clearance is highly predictive for carboplatin elimination (38). Formulas incorporating the glomerular filtration rate (GFR) and AUC have been designed to allow the calculation of the carboplatin dose yielding a pre-defined AUC (40).

At higher dosages of carboplatin (up to $2,400 \mathrm{mg} / \mathrm{m}^{2}$ ), no alterations in drug 
clearance or differences in the rate or route of elimination have been observed. The interpatient variability in pharmacokinetics after high-dose carboplatin has been found to be relatively minor, resulting in a reasonably predictable AUC for patients treated with a given dose of the drug, when the GFR is taken into account (41). Following high-dose carboplatin, presence of the drug can be found in ascites, pleural effusions and in the CSF $(41,42)$.

Myelosuppression is the dose-limiting toxicity of carboplatin (43). In patients treated with a dose of $1,600 \mathrm{mg} / \mathrm{m}^{2}$ carboplatin, profound neutro-and thrombocytopenia have been observed for more than 14 days $(41,44)$. The addition of autologous bone marrow support in patients treated with such high doses of carboplatin has therefore been recommended (41).

Administration of doses up to $400 \mathrm{mg} / \mathrm{m}^{2}$ carboplatin rarely induces renal toxicity in patients with adequate renal function (36). A decrease of renal function of greater than $30 \%$ has been observed in patients receiving high-dose carboplatin, with a temporary loss of more than $80 \%$ of pretreatment renal function in patients receiving $2,400 \mathrm{mg} / \mathrm{m}^{2}(41,44)$.

The principal dose-limiting non-hematological toxicity with high-dose $1 \geqslant 2,000$ $\mathrm{mg} / \mathrm{m}^{2}$ ) carboplatin as a single agent has been reported to be hepatic toxicity, which is characterized by biliary stasis (41). Ototoxicity becomes significant at doses exceeding $1,000 \mathrm{mg} / \mathrm{m}^{2}(41,44)$ and has been found to be more closely related to the cumulative dose of carboplatin than to prior cisplatin therapy (41). Neurotoxicity is also dose-related, but is compounded by prior administration of cisplatin (41, 44).

\section{Thiotepa}

$N, N^{\prime}, N^{\prime \prime}$-triethylenethiophosphoramide (thiotepa) is mainly metabolized to triethylene phosphoramide (tepa) by the hepatic cytochrome P-450 enzyme system (45). Cytotoxicity by thiotepa is thought to be mediated by the formation of DNA interstrand crosslinks (46). However, in vitro studies have also suggested that thiotepa mainly serves as a prodrug for aziridine, which exerts its cytotoxicity by the production of single-strand DNA breaks or alkali-labile DNA-lesions (47). In a similar way, the cytotoxic effect of tepa has been found to differ from its parent compound by the production of alkali-labile DNA-lesions (46). The clinical relevance of these in vitro, however, has not yet been established (46).

Pharmacokinetics and toxicity. Following IV administration, a very rapid and wide tissue distribution of thiotepa has been reported equivalent to that of total body water (48). The terminal half-life of thiotepa has been observed to be independent of dose, with a range from 52 to $212 \mathrm{~min}(49)$. The half-life of its metabolite tepa is considerably longer, ranging from 3 to $21 \mathrm{~h}$ (49).

The AUC of thiotepa has been found to be proportional to the dose, although the relationship is not linear, particularly when doses over $55 \mathrm{mg} / \mathrm{m}^{2}$ are administered. With increasing doses of thiotepa, a concomitant increase of the AUC of tepa is absent. It has therefore been suggested that the metabolism of thiotepa to tepa is an enzymatic process which becomes saturated at lower doses (49). Less than $15 \%$ of thiotepa is bound to plasma proteins as opposed to tepa which is extensively protein-bound and unstable; free tepa cannot usually be measured (50). Thiotepa 
penetrates the CSF. Of the administered dose, $5 \%$ is recovered in the urine as either thiotepa or tepa whereas $24 \%$ is present as non-specific alkylating metabolites, some of which are probably related to aziridine $(47,51)$.

The highest dose of thiotepa that can be given safely intravenously without hematopoietic stem cell support is $65 \mathrm{mg} / \mathrm{m}^{2}$ (49). Phase I studies of high-dose thiotepa in the transplantation setting have demonstrated a maximal tolerated dose of 900 to $1,125 \mathrm{mg} / \mathrm{m}^{2}$ given in divided doses in a $2 \mathrm{~h}$ infusion for 3 days (52).

The dose-limiting toxicity of conventional doses of thiotepa is myelosuppression. The time to the nadir following high-dose thiotepa with autologous bone marrow support is 7 to 10 days. At doses of $405 \mathrm{mg} / \mathrm{m}^{2}$ or more, irreversible bone marrow suppression has been observed (52).

The occurrence of nausea and vomiting is dose-dependent and generally responds well to the administration of standard antiemetics. Mucositis, esophagitis or enterocolitis are most commonly reported in high-dose chemotherapy regimens, and may be difficult to manage after administration of doses exceeding $900 \mathrm{mg} / \mathrm{m}^{2}$ (52). At doses over $1,125 \mathrm{mg} / \mathrm{m}^{2}$, transient elevations of liver enzymes or bilirubin have been encountered (52).

Central nervous system toxicity is the dose-limiting toxicity of high-dose thiotepa. Patients present with symptoms that resembles an organic brain syndrome. At doses of over $1,125 \mathrm{mg} / \mathrm{m}^{2}$, more than $15 \%$ of the patients develop CNS toxicity (52). Skin toxicity consists of an acute erythroderma affecting the palms and soles and a general darkening of the skin which can persist for months but is reversible.

\section{Carmustine (BCNU)}

Carmustine is a chloroethylnitrosourea derivative which is metabolized by hepatic enzymes, but can also be decomposed chemically to produce alkylating products and isocyanates (53). The alkylating products produce DNA-interstrand crosslinks in a two-step reaction sequence. Cytotoxicity is caused by alkylation of the $O^{6}$ position of a guanine followed by interstrand crosslinking with a cytosine on the complementary strand of DNA (54). Cellular resistance to the cytotoxic activity of carmustine mainly occurs through an increase in the enzyme $\mathrm{O}^{6}$-alkylguaninealkyltransferase $\left(0^{6} \mathrm{AT}\right)$ which repairs the alkylated $0^{6}$ guanine (55-57).

Pharmacokinetics and toxicity. Carmustine can only be administered intravenously. After infusion of high-dose $\left(600 \mathrm{mg} / \mathrm{m}^{2}\right)$ carmustine, plasma levels could be detected up to $30 \mathrm{~min}$ following administration (58). The peak concentration was observed at the end of a 2-h infusion and the average half-life was reported to be $22 \mathrm{~min}$ (range 10-33) after discontinuation of the infusion (58). At doses of $600 \mathrm{mg} / \mathrm{m}^{2}$, a large patient-to-patient variation in the clearance has been found, with an AUC ranging from 82 to $887 \mu \mathrm{mol} . \mathrm{min} / \mathrm{l}$. Consequently, there was a considerable variation in drug exposure between patients (58).

Carmustine is highly $(\mathbf{7 7 \%})$ bound to plasma proteins. Similar to other nitrosoureas, carmustine is highly lipophilic and easily crosses the blood-brain barrier. Active pharmacological concentrations can be detected in the central nervous system (59). Within $24 \mathrm{~h}$ following administration, approximately $80 \%$ of the administered carmustine is found in the urine in the form of degradation products (53). 
In conventional doses of carmustine up to $200-300 \mathrm{mg} / \mathrm{m}^{2}$ every 6 to 8 weeks, myelosuppression is the dose-limiting toxicity.

Hepatotoxicity (non-infectious hepatitis or VOD) has been found to be the doselimiting toxicity in high-dose carmustine regimens, with a high incidence of fatal outcomes following doses above 1,200 to $1,500 \mathrm{mg} / \mathrm{m}^{2}(58,60)$. The dose of carmustine and the presence of CNS tumors have been observed to be prognostic factors for the development of severe hepatotoxicity (60).

Immediate drug-related toxicity includes acute cardiovascular effects resulting in hypotension, tachycardia and flushing (58). These effects are dose-related and persist beyond the half-life of carmustine. The underlying mechanism for this phenomenon is unknown. Cardio-toxicity, expressed as cardiac necrosis by pathologic examination, has rarely been described at cumulative doses over $3,000 \mathrm{mg} / \mathrm{m}^{2}$ (60).

Carmustine-related interstitial pneumonitis has frequently been observed at doses of $1,000 \mathrm{mg} / \mathrm{m}^{2}$ or more, but is probably not strictly dose-related (60). (Fatal) pulmonary toxicity has been encountered up to 17 years after administration of carmustine $(61,62)$. The role of corticosteroid treatment in these patients still remains unclear $(60,62)$.

Delayed renal toxicity has been documented following cumulative doses of 1,500 $\mathrm{mg} / \mathrm{m}^{2}(59)$, although in a large phase I-II study when carmustine was administered in doses up to $2,850 \mathrm{mg} / \mathrm{m}^{2}$, nephrotoxicity did not develop (60). Encephalomyelopathy has been encountered in patients receiving more than 2,000 $\mathrm{mg} / \mathrm{m}^{2}$ carmustine (60).

\section{Mitoxantrone}

Mitoxantrone is a hydroxyquinone, which is structurally related to doxorubicin but lacks the amino sugar moiety (63). It has been suggested that mitoxantrone, unlike the classical intercalating agents, binds to DNA by non-intercalative electrostatic interactions (64). Induction of DNA-protein crosslinks by mitoxantrone has also been reported $(65,66)$. DNA breakage by stabilization of a complex between DNA and topoisomerase II, caused by mitoxantrone, suggests additive cytotoxicity through topoisomerase II inhibition (67). The precise mechanism of antitumor activity of mitoxantrone, however, remains to be elucidated (68). The cellular toxicity of mitoxantrone is cell-cycle non-specific; in vitro the drug is cytotoxic for both proliferating and non-proliferating cells (65).

Pharmacokinetics and toxicity. Following intravenous administration, the plasma clearance rate has been described according to biphasic and triphasic models, with terminal half-lives of 37.4 and $42.6 \mathrm{~h}$, respectively $(69,70)$. Mitoxantrone is extensively bound to plasma proteins ( $>95 \%)$, blood cells and body tissues $(70)$. The main route of excretion is in the bile with less than $7 \%$ of the drug being eliminated in the urine. In patients with hepatic dysfunction, a decreased total body clearance rate of mitoxantrone has been observed, suggesting that the dose of mitoxantrone should be adjusted in these patients (69).

The dose-limiting toxicity of mitoxantrone is myelosuppression, predominantly granulocytopenia, with a cumulative effect on bone marrow function following repetitive administration $(66,71,72)$. The maximum tolerated dose is $12-14 \mathrm{mg} / \mathrm{m}^{2}$, 
when administered as a single bolus injection intravenously every 3 weeks (72). The degree of myelosuppression appears to be related to prior therapy, the presence of bone marrow involvement and the performance status of the patient (63).

Mitoxantrone has not been investigated as a single-agent in dose escalation studies. Stomatitis and mucositis are dose-dependent and appear to be the doselimiting toxicities in high-dose mitoxantrone-based regimens (73). In combination with high-dose alkylating agents and autologous bone marrow support, the MTD is $60 \mathrm{mg} / \mathrm{m}^{2}(71,73)$. The degree of nausea, vomiting and diarrhea at this dose-level has been reported to be mild to moderate and minor signs of liver toxicity are common (71).

The development of cardiac toxicity is related to pre-existing risk-factors such as underlying cardiovascular disease, prior anthracycline exposure and prior mediastinal radiation $(63,71)$. Following standard doses of mitoxantrone, clinically significant cardiotoxicity has been observed in about $3 \%$ of patients with a poor performance status, who had previously been treated with anthracyclines (74). Overall, the incidence of congestive heart failure increases with cumulative doses of over $100 \mathrm{mg} / \mathrm{m}^{2}$ in patients who have had previously received anthracyclines and with a cumulative dose of $160 \mathrm{mg} / \mathrm{m}^{2}$ or more in patients without prior treatment (71).

\section{Melphalan}

DNA lesions caused by melphalan ( $L$-phenylalanine mustard) are produced by a mustard-like reactive intermediate (75). Cytotoxicity is induced by the formation of DNA-crosslinks and melphalan acts as a cell-cycle non-specific alkylator.

Melphalan is transported into the cell through a high-affinity carrier, the l-amino acid transport system, which is also responsible for the transport of the amino acids leucine and glutamine. Alterations in the amino acid content of plasma or malignant effusions may therefore influence the uptake and cytotoxicity of this drug (76).

Pharmacokinetics and toxicity. Following the intravenous administration of highdose (140-240 $\left.\mathrm{mg} / \mathrm{m}^{2}\right)$ melphalan, pharmacokinetic parameters have been shown to be independent of dose and highly variable between patients. It has therefore been suggested to individualize the dose of melphalan by prior pharmacokinetic characterization of each patient; a test-dose should be given to determine the clearance and should then be followed by the administration of a calculated dose aimed to achieve an optimal target AUC (77). To our knowledge, such a procedure has not been implemented in clinical trials.

Immediately following i.v. administration, up to $50 \%$ of melphalan will bind to plasma proteins, which increases in time to over $90 \%(78)$. The plasma elimination half-life is short, with a $t_{1 / 2} \alpha$ of 6 to $10 \mathrm{~min}$ and a $t_{1 / 2} \beta$ of $40 \mathrm{~min}$ to $2 \mathrm{~h} \mathrm{(77).} \mathrm{Hydrolysis}$ to dihydroxymelphalan is the main route of elimination (75). Less than $15 \%$ of the intact drug is excreted in the urine which explains why alterations in renal function have not been shown to influence melphalan pharmacokinetics significantly (77). The CSF to plasma ratio is less than $10 \%$.

The dose-limiting toxicity of conventional doses of melphalan consists of myelosuppression. When high-dose i.v. melphalan is administered with autologous bone marrow support, gastrointestinal toxicity is usually dose-limiting. Its major 
manifestations are stomatitis and diarrhea (79). Pretreatment with cyclophosphamide appears to reduce the degree of melphalan-associated gastrointestinal toxicity. The maximum tolerated single dose is up to $245 \mathrm{mg} / \mathrm{m}^{2}$ as compared with $170 \mathrm{mg} / \mathrm{m}^{2}$ in patients not primed with cyclophosphamide (79). In addition, bone marrow recovery following high-dose melphalan has been documented to be accelerated by cyclophosphamide pretreatment (80).

\section{Busulfan}

Busulfan is a bifunctional alkylating agent which produces protein-DNA and intrastrand DNA crosslinks. The agent is mainly active on cells in the G0 or G1 phase of the cell cycle (81).

Pharmacokinetics and toxicity. Busulfan is only available as an oral preparation; a dose of $1 \mathrm{mg} / \mathrm{kg}$ every $6 \mathrm{~h}$ for 4 days is commonly used in high-dose regimens. The peak plasma concentration is reached $50 \mathrm{~min}$ to $3 \mathrm{~h}$ after a single administration. Steady-state concentrations are reached after 2-3 doses (82). Following repeated administration, the clearance of busulfan increases, whereby the half-life decreases, indicating that the drug accelerates its own metabolism (82). The mean elimination half-life is about $2 \mathrm{~h}$ (83).

Busulfan is highly lipophilic and is for less than $55 \%$ bound to plasma-proteins. The combination of these properties may partially explain the high CSF/plasma ratio observed with high-dose busulfan $(82,84)$. Busulfan is partially metabolized through reactions with glutathione. This process is catalysed by glutathione-Stransferase and results in three recently discovered urinary metabolites (82).

The dose-limiting toxicity of high-dose busulfan is VOD of the liver (83). Although VOD is the second leading cause of death in patients receiving autologous bone marrow transplantation, the pathogenesis of this clinical syndrome remains obscure. Multivariate logistic regression analysis has shown the AUC to be the only significant pharmacokinetic predictor of the development of VOD following highdose busulfan (83).

Neurotoxicity occurs during administration of high-dose busulfan in $10 \%$ of patients. This neurotoxicity, characterized by the occurrence of seizures, is transient and without sequelae (84). Other reported side-effects include interstitial pulmonary fibrosis following prolonged administration, and an Addison's disease-like syndrome characterized by cutaneous hyperpigmentation and general weakness but without adrenal insufficiency. Radiation therapy following high-dose busulfan induces enhanced skin radiation side-effects (85).

\section{Etoposide}

Etoposide is a semisynthetic epipodophyllotoxin derivative. This drug is most toxic in the late $S$ or early $\mathrm{G} 2$ phase of the cell cycle, thereby inducing a pre-mitotic block (86). Etoposide causes dose-dependent single-and double-stranded breaks in DNA, DNA-protein crosslinks and chromosomal aberrations. Interference with the function of the enzyme DNA-topoisomerase II is thought to underly the mechanism of DNA strand breakage induced by the epipodophylotoxines. 
Pharmacokinetics and toxicity. Pharmacokinetic parameters of etoposide show a considerable interpatient variability. The AUC and the peak plasma concentration are both linearly related to the dose of etoposide. The half-life is independent of the dose with a terminal elimination half-life ranging from 4 to $8 \mathrm{~h}(86)$.

More than $95 \%$ of etoposide is bound to plasma proteins. Following high-dose intravenous administration, presence of etoposide in the CSF has been observed (87). Etoposide is predominantly excreted in the urine, $20-45 \%$ as unchanged drug and $20-33 \%$ as metabolites; excretion of etoposide by the hepatobiliary route is negligible (86).

In contrast with alkylating agents, the efficacy of etoposide strongly depends on the schedule of administration. Divided doses administered over 3 to 5 days have been shown to be superior to a single dose. A plasma concentration of above $1 \mu \mathrm{g} / \mathrm{ml}$ appears to be essential for its antitumor activity.

Following administration of high-dose etoposide $\left(800-3500 \mathrm{mg} / \mathrm{m}^{2}\right)$ with bone marrow support, reversible mucositis is the dose-limiting toxicity (88). Nausea and vomiting are not dose-related $(88,89)$. Acute hypersensitivity reactions have been reported infrequently (90).

\section{Mitomycin C}

Mitomycin $\mathrm{C}(\mathrm{MMC})$ is an antibiotic originating from Streptomyces caespitosus. $M M C$ is a bioreductive alkylating agent producing DNA-protein crosslinks and DNAinter- and intrastrand crosslinks; the drug is most effective in the late G1 and early $\mathrm{S} 1$ phases of the cell cycle $(91,92)$.

Pharmacokinetics and toxicity. The pharmacokinetic behavior of MMC is linear and fits a 2-compartment model (93). After intravenous bolus administration, MMC is rapidly cleared from the plasma. Major routes of elimination are liver metabolism and renal excretion. The $t_{1 / 2} \alpha$ varies from 6 to $17 \mathrm{~min}$; the $t_{1 / 2} \beta$ is between 28 and $112 \mathrm{~min}(94)$. Up to $20 \%$ is excreted unchanged in the urine, mainly by glomerular filtration (93). Renal excretion of MMC is independent of renal function.

The dose-limiting toxicity of MMC is delayed and cumulative myelosuppression. The non-hematological toxicities observed in high-dose MMC regimens with autologous bone marrow support have been considerable and were the reason to discontinue the use of MMC in high-dose chemotherapy regimens (95). These toxicities included severe, and sometimes lethal side-effects, such as VOD of the liver, interstitial pneumonitis, frequently associated with pulmonary fibrosis, and intractable congestive heart failure. The latter has predominantly been observed in patients previously treated with anthracyclines (94-97). Gastrointestinal toxicity has been reported to be cumulative following sequential high-dose MMC administration (95). The hemolytic uremic syndrome associated with a high mortality may occur several months after MMC therapy in $0.5-8 \%$ of patients (94).

\section{High-dose combination regimens}

A variety of high-dose chemotherapy regimens with autologous bone marrow or peripheral stem cell support are currently under clinical evaluation in solid tumors. 
The majority are multiple-alkylating agent based combinations, for reasons well described by Frei and Teicher (98-102). In the following section, the high-dose chemotherapy regimens most frequently investigated in the treatment of solid tumors will be described. Since randomized studies are not yet available and the current studies vary widely with respect to patient selection, induction chemotherapy regimens and definition of response duration, this section will mainly focus on feasibility and toxicity. An overview of the studies discussed is presented in Table 2.

\section{Cyclophosphamide-thiotepa based combinations}

Cyclophosphamide and thiotepa were among the first alkylating agents to be used in high-dose chemotherapy regimens. This was based on the results of studies performed by Frei and Teicher, who demonstrated synergistic activity in vitro between these two agents $(99,100)$. In 1987, Williams et al., reported the administration of high-dose cyclophosphamide and thiotepa in patients with advanced cancer (103). As confirmed in subsequent studies (104-106), the main extramedullary toxicity of this bi-alkylator regimen is mucositis. A wide range in the number of toxic deaths has been reported in different studies. Toxic deaths have been primarily caused by infectious complications following severe bone marrow suppression. These differences in fatal toxicity may be explained in part by differences in patient selection.

Phase II studies with high-dose cyclophosphamide and thiotepa in metastatic breast cancer have shown considerable differences in response rates, and the response durations were usually brief $(105,106)$. In animal studies, the cytotoxicity of the combination of cyclophosphamide and thiotepa depends on the schedule of administration (107). Simultaneous administration of cyclophosphamide and thiotepa appears to be inferior to sequential dosing. The optimal interval between the administration of both drugs was $8 \mathrm{~h}$, irrespective of the sequence (107). When cyclophosphamide and thiotepa were injected within a 4-h interval, additional tumor-cell kill was only achieved when thiotepa was administered first (107). In clinical studies, information about the sequencing of the alkylating agents is rarely reported; whether differences in scheduling contribute to the differences in response rates observed, remains to be elucidated.

Since alkylating agents can have different mechanisms of DNA damage and generally lack cross-resistance, the addition of a third alkylator to this combination was hoped to reduce the likelihood of resistance further and to increase dose intensity (108).

Cyclophosphamide, thiotepa and carboplatin. In the Solid Tumor Autologous Marrow Program (STAMP) of Antman and co-workers, melphalan was initially added to the combination of cyclophosphamide and thiotepa (STAMP III). Due to lifethreatening mucositis in the first two patients, the combination was considered too toxic and was subsequently abandoned (104). The substitution of melphalan by carboplatin as the third alkylating agent resulted in the well-known STAMP V (CTCb) regimen (109). A phase II trial which included 29 patients with metastatic breast cancer, confirmed the results of the preceding phase I study, and showed that CTCb is a regimen with acceptable morbidity and a low mortality rate (110). This was 


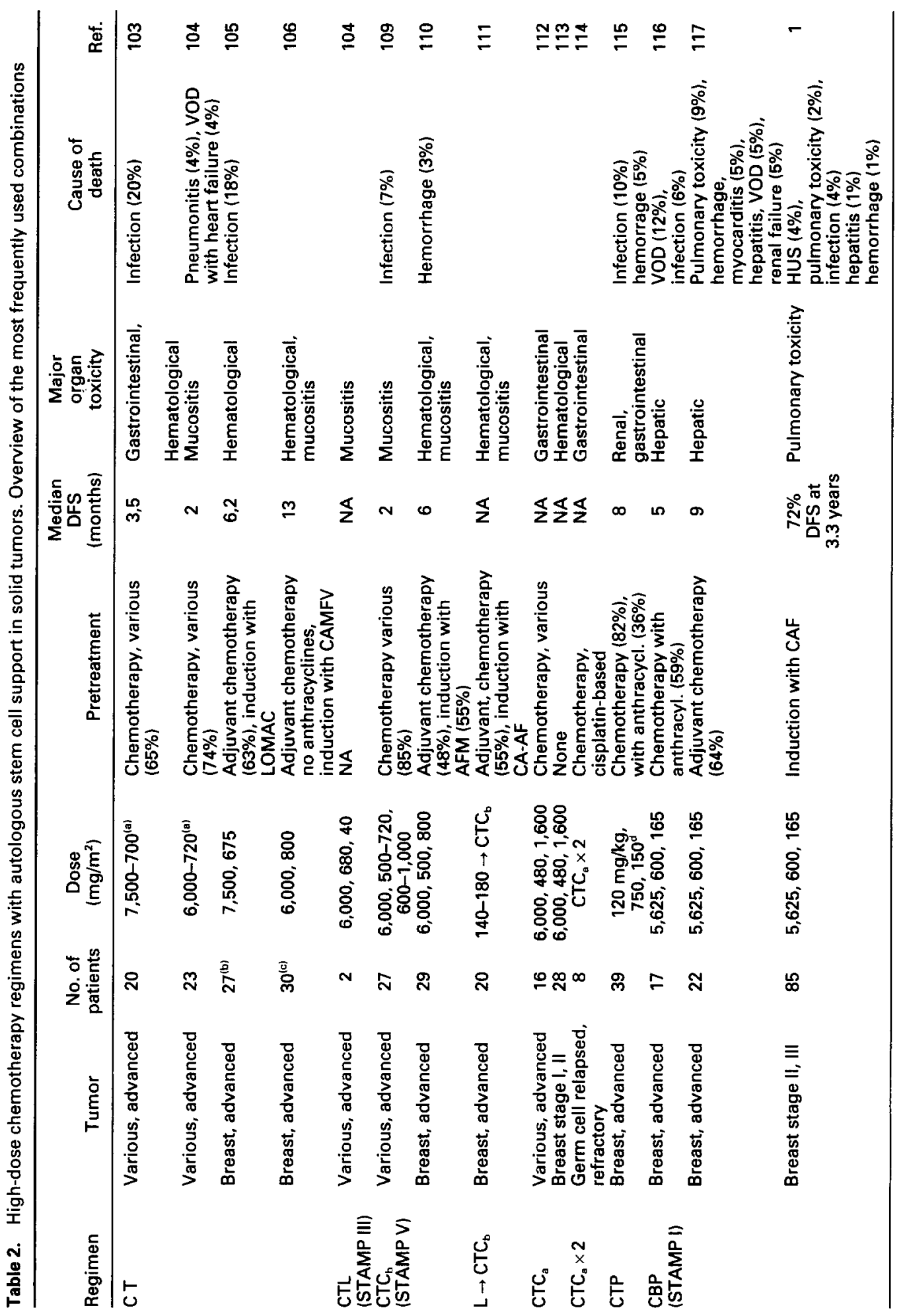




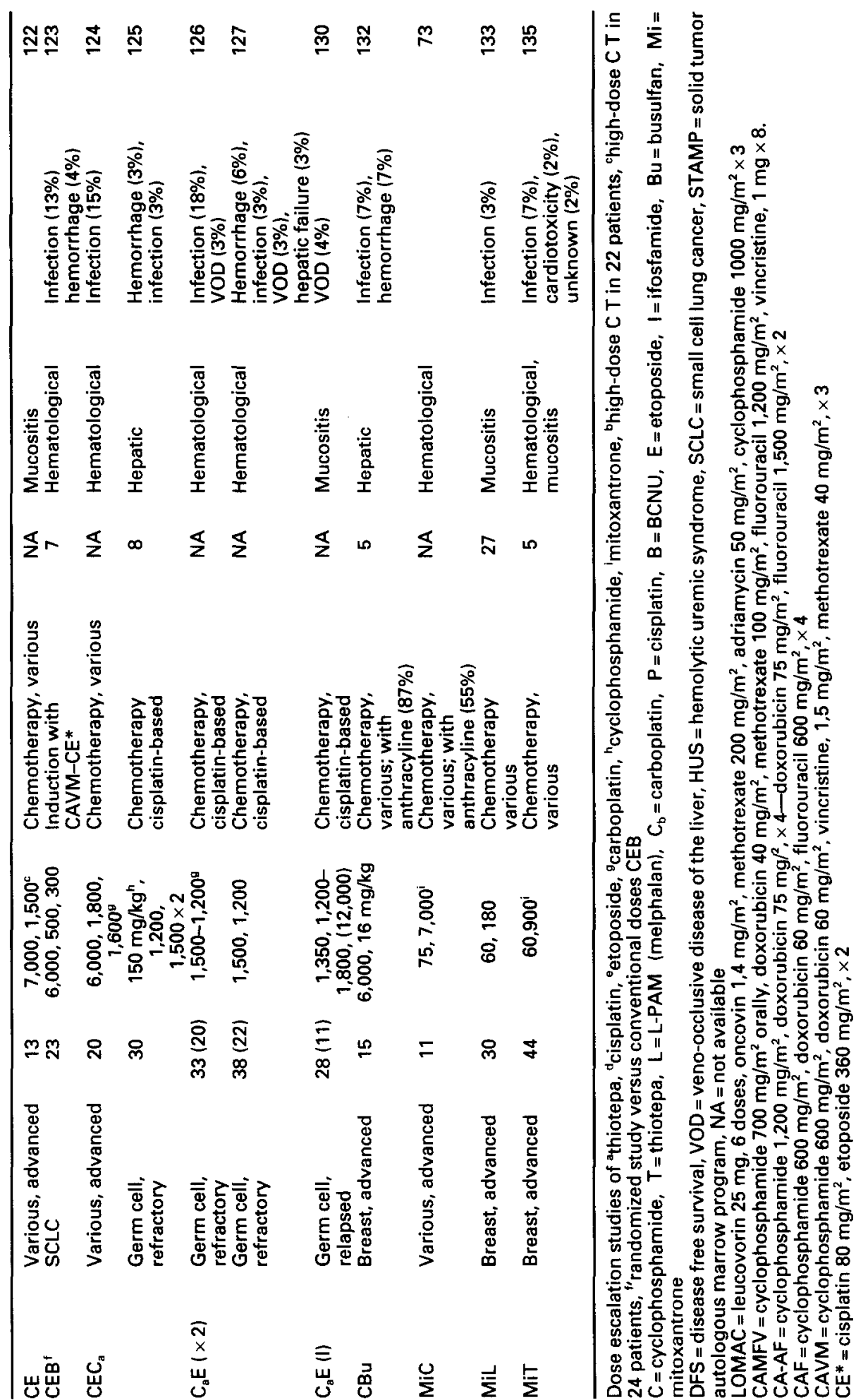


confirmed in later studies, in which $\mathrm{CTCb}$ was preceded by high-dose melphalan (111). In the $\mathrm{CTCb}$ phase I study, the occurrence of severe stomatitis prevented further dose-escalation (109) and the MTDs were established at cyclophosphamide $6,000 \mathrm{mg} / \mathrm{m}^{2}$, thiotepa $500 \mathrm{mg} / \mathrm{m}^{2}$, and carboplatin $800 \mathrm{mg}$ per $\mathrm{m}^{2}(110,111)$.

In the Netherlands Cancer Institute, a similar high-dose regimen has been developed. The dose of carboplatin is, however, twice that of the STAMP V regimen (i.e. $1600 \mathrm{mg} / \mathrm{m}^{2}$ ), but the dose of thiotepa is similar (i.e. $\left.480 \mathrm{mg} / \mathrm{m}^{2}\right)(112)$. The total dose of cyclophosphamide is identical, $6000 \mathrm{mg} / \mathrm{m}^{2}$. In spite of the high carboplatin dose, this CTC regimen has been shown to be well-tolerated without severe nonhematological toxicity, even when administered sequentially in a tandem transplantation setting $(113,114)$. Mucositis was manageable, requiring total parenteral nutrition in only few patients (113). In eight heavily pretreated patients receiving two cycles of high-dose CTC-chemotherapy, some oto-and neurotoxicity were observed. All patients had been pretreated with cisplatin (114). Toxic deaths were not observed in either study, which included $60 \mathrm{CTC}$ courses in a total of 52 patients (112-114).

Cyclophosphamide, thiotepa and cisplatin. Recently, Ghalie and co-workers published data on a high-dose regimen incorporating cyclophosphamide, thiotepa and cisplatin in a split-course schedule for metastatic breast cancer (115). It was hypothesized that by applying this schedule of administration, the occurrence of toxic side-effects would be reduced, allowing further dose-escalation. The toxicity of this regimen, however, was considerable, contributing to a $15 \%$ toxic death rate. All 39 patients developed neutropenic fevers requiring the administration of aminoglycosides, which, in combination with high-dose cisplatin, may have contributed to the high incidence of renal toxicity observed $(32,115)$.

\section{Cyclophosphamide, BCNU (carmustine), and cisplatin based combinations}

Among the most comprehensively investigated intensification regimens is the STAMP 1 regimen, which consists of cyclophosphamide, BCNU and cisplatin (CBP). In a phase I study, the MTD of this triple-alkylating regimen was reported to be 5,625 , 600 and $165 \mathrm{mg} / \mathrm{m}^{2}$ respectively (116). The major dose-limiting toxicity consisted of hepatotoxicity, and the development of (fatal) VOD. Thrombocytopenia-associated hemorrhage occurred only at higher dose levels in contrast to pulmonary toxicity which was not dose-related $(116,117)$. The addition of melphalan resulted in unacceptable renal and gastrointestinal toxicity (116). Therefore this agent was subsequently omitted from the regimen.

The MTD of combination therapy with CBP for metastatic breast cancer has been associated with considerable treatment-related toxicity, including VOD, gastrointestinal hemorrhage and a mortality rate of $14 \%(118)$. This was thought to be, at least partly, due to the cumulative effects of extensive pretreatment. Attempts were made to reduce toxicity by including only those patients who had not received prior chemotherapy for metastatic disease (119). Treatment-related toxicity, however, remained substantial and was also confirmed in a subsequent study that evaluated the role of CBP dose-intensification in stage II-III breast cancer (1). The pattern of toxicity was not affected by omitting cisplatin. Following high-dose cyclophosphamide and $\mathrm{BCNU}$, major organ toxicities remained similar to those 
observed with CBP, i.e. pulmonary and hepatic toxicity $(119,120)$. The substitution of cisplatin with carboplatin resulted in the development of severe VOD in three out of four patients (121). The death in two out of three of these patients led to the conclusion that the use of carboplatin in this combination was not feasible (121).

\section{Cyclophosphamide-etoposide based combinations}

The majority of the cyclophosphamide-etoposide based intensification regimens have been investigated for their efficacy in small cell lung cancer (SCLC) and in germ cell cancer. In a phase I study with cyclophosphamide and escalating doses of etoposide, mucositis of the upper gastrointestinal tract was the dose-limiting toxicity. Cyclophosphamide $7,000 \mathrm{mg} / \mathrm{m}^{2}$ and etoposide $1,500 \mathrm{mg} / \mathrm{m}^{2}$ were recommended for further investigation. In addition, the dose of etoposide was considered sufficient to produce effective concentrations in the central nervous system $(88,122)$.

Cyclophosphamide, etoposide, and BCNU (CEB). In 1987, the results of the first randomized study were published which evaluated the role of high-dose chemotherapy in 45 patients with SCLC (123). Following induction chemotherapy, which included cyclophosphamide and etoposide, responding patients were randomized to either CEB at the conventional dosages of $750 \mathrm{mg} / \mathrm{m}^{2}, 600 \mathrm{mg} / \mathrm{m}^{2}$ orally and $60 \mathrm{mg} / \mathrm{m}^{2}$ respectively, or a high-dose CEB, consisting of cyclophosphamide $6,000 \mathrm{mg} / \mathrm{m}^{2}$, etoposide $500 \mathrm{mg} / \mathrm{m}^{2}$ and $\mathrm{BCNU} 300 \mathrm{mg} / \mathrm{m}^{2}$. The median disease-free survival, from the time of randomization, was 7 months in the high-dose CEB-arm, compared to 2.5 months in the control arm $(p=0.002)$ (123). However, a significant difference in overall survival could not be established, which was partly due to the high percentage of deaths during the period of bone marrow aplasia following high-dose CEB. It was suggested that improvement in supportive care and the use of alternative agents, such as carboplatin, might eventually contribute to an increase in the efficacy of high-dose chemotherapy in this patient group (123).

Cyclophosphamide, etoposide and carboplatin (CEC). Two phase I studies have evaluated the feasibility of a high-dose CEC chemotherapy regimen with ABMT or peripheral blood stem cell transplantation (PSCT) $(124,125)$. Both studies applied a dose-escalation schedule for one of the two alkylating agents. Dose-escalation of carboplatin resulted in acute renal failure as the dose-limiting toxicity (124). This occurred in two of 14 patients who had received a dose of $1,600 \mathrm{mg} / \mathrm{m}^{2}$ carboplatin. Both patients had previously been treated with cisplatin and/or carboplatin and were 'markedly obese'. The dose of carboplatin had been prescribed on the basis of their total body weight, and both had creatinine clearances of slightly above $60 \mathrm{ml} / \mathrm{min}$ prior to the administration of CEC. If the creatinine clearance had been expressed as clearance according to the standard body surface area of $1.74 \mathrm{~m}^{2}$, it would have been below $60 \mathrm{ml} / \mathrm{min}$ in both patients. The investigators therefore suggested that the dose of carboplatin should have been adjusted to ideal body weight in order to prevent overdosing and serious renal damage (124).

In a subsequent study in 30 patients with cisplatin-refractory germ cell cancer, dose-escalation of cyclophosphamide with fixed doses of carboplatin $\left(1500 \mathrm{mg} / \mathrm{m}^{2}\right)$ and etoposide $\left(1200 \mathrm{mg} / \mathrm{m}^{2}\right)$ was evaluated (125). Fourteen patients who responded 
to the first course were retreated. The second cycle was administered 4 to 6 weeks after hematologic recovery. Two toxic deaths occurred related to myelosuppression, while other major toxicity involved the liver, manifested as cholestasis which occurred in 17 patients $(57 \%)$; VOD was not observed (125). Interestingly, the seven patients $(23 \%)$ who achieved a durable complete remission, at a median follow-up of 11.4 months (range 5.6-35.5), were those who received two courses of high-dose CEC. The two patients who achieved a complete response after a single course of CEC were not retreated and subsequently relapsed (125).

\section{Carboplatin-etoposide based combinations}

The combination of high-dose carboplatin and etoposide followed by autologous bone marrow rescue has particularly been applied in relapsing or refractory germ cell cancer. In a phase I study performed in the Indiana University programme, the MTD of carboplatin was $1500 \mathrm{mg} / \mathrm{m}^{2}$ in combination with etoposide $1200 \mathrm{mg} / \mathrm{m}^{2}$ (126). The dose-limiting toxicity was enterocolitis; toxic deaths $(21 \%)$ were observed and doses above $1500 \mathrm{mg} / \mathrm{m}^{2}$ carboplatin. At these dose levels, hepatic toxicity developed in eight patients (24\%) with a fatal outcome in one (126).

The feasibility and efficacy of combination therapy with carboplatin $1500 \mathrm{mg} / \mathrm{m}^{2}$ and etoposide $1200 \mathrm{mg} / \mathrm{m}^{2}$ was subsequently investigated in a phase II trial in refractory germ cell cancer (127). Patients who responded to the first high-dose chemotherapy cycle, received a second one. Five of 38 patients $(13 \%)$ remained disease-free for more than 1 year. However, the toxicity of this regimen was substantial including treatment-related deaths in five patients $(13 \%)$. All deaths occurred after the first transplantation (127). Toxic deaths were due to sepsis, hemorrhage or hepatic failure, including one VOD. Patients with refractory mediastinal germ cell tumors did not appear to benefit from this high-dose chemotherapy regimen and were therefore excluded from further studies $(127,128)$.

In an attempt to improve the efficacy, ifosfamide has been added to the highdose carboplatin-etoposide regimen (129). Severe renal toxicity was, however, observed at the first dose level $\left(10 \mathrm{~g} / \mathrm{m}^{2}\right)$, which precluded the planned further dose escalation. This is in contrast to data available from an Italian multicenter study, in which 11 patients received $12 \mathrm{~g} / \mathrm{m}^{2}$ ifosfamide, $1350 \mathrm{mg} / \mathrm{m}^{2}$ carboplatin and 1200 $\mathrm{mg} / \mathrm{m}^{2}$ etoposide (130). No renal toxicity was observed despite the simultaneous administration of the aminoglycoside antibiotic amikacine in some of these patients. Severe mucositis was the major toxicity recorded. Neurotoxicity has not been observed in either of the high-dose single-agent ifosfamide studies $(129,130)$.

\section{Cyclophosphamide-busulfan based combinations}

Limited data are available on the use of high-dose cyclophosphamide and busulfan in solid tumors. In hematological malignancies it is a well-known preparative regimen for autologous or allogeneic bone marrow transplantation (131).

A phase II study has been published recently which investigated the administration of high-dose cyclophosphamide and busulphan in 15 patients with advanced breast cancer (132). Despite a high complete response rate, the response duration was brief. Hyperbilirubinemia developed in three patients $(20 \%)$ without 
clear-cut evidence of VOD; two patients (13\%) died of treatment-related toxicity, the first due to sepsis and the second following diffuse alveolar hemorrhage (132).

\section{Mitoxantrone based combinations}

Mitoxantrone and melphalan. A high-dose chemotherapy regimen which included mitoxantrone has been used in advanced breast cancer (133). Thirty patients who were in complete remission after standard-dose chemotherapy, received a combination of mitoxantrone, $60 \mathrm{mg} / \mathrm{m}^{2}$, and melphalan, $180 \mathrm{mg} / \mathrm{m}^{2}$-supported by ABMT or PSCT. This resulted in a median disease-free survival (DFS) of 27 months and a $43 \%$ DFS at 3 years (133). In an earlier study, cyclophosphamide had been substituted by melphalan when the combination of high-dose cyclophosphamide and mitoxantrone frequently resulted in hemorrhagic cystitis (73) and cardiotoxicity (134). Significant cardiotoxicity has not been reported for the combination of mitoxantrone and melphalan, despite the inclusion of patients previously treated with anthracyclines or those having received external thoracic radiation $(132,133)$. The major toxicity of this regimen is mucositis (133).

Mitoxantrone and thiotepa. A dose-escalation study of mitoxantrone administered with thiotepa for metastatic breast cancer has recently been published (135). The dose-limiting toxicity of mitoxantrone in combination with thiotepa, $900 \mathrm{mg} / \mathrm{m}^{2}$, appeared to be cardiotoxicity. The MTD of mitoxantrone was $50 \mathrm{mg} / \mathrm{m}^{2}$ (135). Infectious complications and severe mucositis were other frequently encountered toxicities of this regimen.

Mitoxantrone and carboplatin. Mitoxantrone, $40-50 \mathrm{mg} / \mathrm{m}^{2}$, in combination with carboplatin, $1500 \mathrm{mg} / \mathrm{m}^{2}$, has little or no activity in the treatment of breast cancer and is associated with considerable toxicity (136).

\section{Discussion}

Until recently, high-dose chemotherapy with autologous stem cell support in solid tumors had almost exclusively been evaluated in small feasibility-or phase II studies. Compelling reasons not to proceed to prospective randomized studies included the high cost of treatment, the need for prolonged hospitalization, the extensive toxicity and the significant treatment-related mortality rates. Dramatic advances in the technology of supportive care and essential information on the toxicity of highdose regimens specifically designed for solid tumors are currently changing the scene. Several randomized phase III studies are now in progress to study the role of high-dose adjuvant chemotherapy in high-risk breast cancer and many more studies are being designed for advanced breast cancer, germ cell cancer and ovarian cancer.

Several non-randomized studies utilizing historical controls have suggested substantial advantages of high-dose therapy over conventional treatment. High-dose therapy has been shown to achieve long-term disease-free survival in some patients with incurable germ cell cancers and many oncologists (and patients) believe that high-dose therapy may become the standard for adjuvant chemotherapy in breast 
cancer patients with unfavorable characteristics. Randomized studies are urgently needed to substantiate these claims. At the same time, high-dose therapy is rapidly evolving and regimens and techniques that appear to be adequate today may be viewed as outdated next year. It is quite possible that some high-dose regimes will eventually prove to be associated with significant cure rates in certain tumors, while others may not. Meaningful comparisons of efficacy are impossible at this stage (Table 2), and the treatment results in individual studies may illustrate patient selection rather than the choice of agents and doses in the chemotherapy regimen.

The selection of agents to be included in a high-dose regimen is essentially based on a number of theoretical considerations that currently lack sufficient clinical confirmation. For example, it is commonly believed that each agent in a high-dose regimen should have activity in the relevant tumor type at conventional doses. Agents that have steep dose-response curves in vitro or in animal systems aie preferred and combinations of drugs that show little cross-resistance in vitro are particularly attractive. Most alkylating agents share these properties and since the dosages of many of these can be escalated several times in humans before doselimiting organ toxicity appears, multiple alkylator regimens are currently in favor (98-102).

In the absence of convincing evidence that one regimen is more active than the other, it is reasonable to focus on toxicity if a regimen must be selected for a randomized study. This is even more important if the study aims to evaluate highdose therapy in the adjuvant setting, especially when some patients may already be cured. The level of toxicity is often difficult to determine from the published literature. The treatment-related death rate, for instance, may be influenced significantly by the performance status and extent of pre-treatment. It may depend on the experience and expertise of the investigators, and it may be influenced by the type of supportive care employed. Nevertheless, it is clear that certain drugs are associated with severe organ toxicities (Table 1). Busulfan, mitomycin $C$ and BCNU are associated with VOD and the latter two may also cause interstitial pneumonitis. Both toxicities are not strictly dose-dependent, but are frequently fatal. Cisplatin and ifosfamide have been associated with acute renal failure when administered in high doses. In addition, high-dose cisplatin is associated with severe and irreversible hearing loss and neuropathy, both of which may significantly impair the quality of life in survivors.

The alkylating agents cyclophosphamide, thiotepa, carboplatin and melphalan are not associated with irreversible or unpredictable fatal organ toxicities and have been studied widely in high-dose regimens. The dose of each of these agents can be escalated at least four-fold if adequate supportive care is employed, and all have a broad-spectrum activity in solid tumors. Combinations of cyclophosphamide, thiotepa and carboplatin have been studied by several groups and found to be safe and tolerable (Table 2). The addition of melphalan to cyclophosphamide and thiotepa appeared to be associated with severe mucositis and was therefore abandoned by the Boston group (104). Thus, combinations of cyclophosphamide, thiotepa and carboplatin may presently be considered the most suitable triplealkylator regimens for adjuvant chemotherapy studies in solid tumors. It must be stressed, however, that this statement is tentative and that randomized studies will be required to confirm or deny it.

If one assumes that a combination of cyclophosphamide, thiotepa and car- 
boplatin constitutes a suitable basis for a high-dose regimen, the relevant question is whether or not a single course of this regimen is sufficient. Tandem high-dose regimens have been shown to be feasible and clearly lead to a further increase in dose intensity. Recent experience from the Boston group has shown that $\mathrm{CTCb}$ can be administered shortly after a course of high-dose single-agent melphalan (111), and experience in our institute has shown that two courses of CTC can be delivered safely within 6 weeks (114). Employing autologous peripheral stem cell transplantation and-eventually-ex vivo expansion of progenitor cells may enable investigators to administer three or even four courses of high-dose therapy at only 3- or 4-week intervals. There is little doubt that the feasibility of these approaches will be limited by organ toxicities other than myelosuppression.

\section{References}

1. Peters, W. P., Ross, M., Vredenburgh J. J., Meisenberg, B., Marks, L. B., Winer, E., Kurtzberg, J., Bast, R. C. Jr, Jones, R., Shpall, E., Wu, K., Rosner, G., Gilbert, C., Mathias, B., Coniglio, D., Petros, W., Henderson, I. C., Norton, L., Weiss, R. B., Budman, D. \& Hurd, D. (1993) Highdose chemotherapy and autologous bone marrow support as consolidation after standard-dose adjuvant therapy for high-risk primary breast cancer. J. Clin. Oncol. 11: 1132-1143.

2. Mulder, N. H., Sleijfer, D. Th, De Vries, E. G. E., Mulder, P. O. M., vd Graaf, W. T. A., vd Ploeg, E., Dolsma, W. V. \& Willemse, P. H. B. (1993) Intensive chemotherapy with autologous bone marrow reinfusion in patients with breast cancer and more than 5 involved lymph nodes. Proc. Am. Soc. Clin. Oncol. 12: 76 (Abstr 104).

3. Overmoyer, B., Dannely, R., Goormastic, M., Andresen, S., Lichtin, A. \& Bolwell B. (1994) Consolidation for high risk breast cancer with high dose chemotherapy and autologous bone marrow rescue. Proc. Am. Soc. Clin. Oncol. 13: 93 (Abstr 174).

4. Livingston, R. B. (1994) High-dose consolidation for stage IV breast cancer. In: Educational book of the American Society of Clinical Oncology; Dallas, TX: American Society of Clinical Oncology, pp. 74-79.

5. Philip, Pr. T. (1993) Breast carcinoma: 203 patients In: European Group for Bone Marrow Transplantation, Working Party Solid Tumor Registry. Report Garmisch-Partenkirchen meeting. February 1993: 94-96.

6. Coiffier, B., Philip, T., Burnett, A. K. \& Symann, M. L. (1994) Consensus conference on intensive chemotherapy plus hematopoietic stem-cell transplantation in malignancies: Lyon, France, June 4-6, 1993. J. Clin. Oncol. 12: 226-231.

7. Sladek, N. E., Doeden, D., Powers, J. F. \& Krivit, W. (1984) Plasma concentrations of 4-hydroxycyclophosphamide and phosphoramide mustard in patients repeatedly given high doses of cyclophosphamide in preparation for bone marrow transplantation. Cancer Treat. Rep. 68: 1247-1254.

8. Colvin, M., Brundett, R. B., Kan, M. N. N., Jardine I. \& Fenselau, C. (1976) Alkylating properties of phosphoramide mustard. Cancer Res. 36: 1121-1126.

9. Cox. P. J. (1979) Cyclophosphamide cystitis-identification of acrolein as the causative agent. Biochem. Pharmacol. 28: 2045-2049.

10. Eder, J. P., Elias, A. D., Ayash, L., Wheeler, C. A., Shea, T. C., Schnipper, L. E., Frei, E. III \& Antman, K. H. (1991) A phase I trial of continuous-infusion cyclophosphamine in refractory cancer patients. Cancer Chemother. Pharmacol. 29: 61-65.

11. Fasola, G., Lo Greco, P., Calori, E., Zilli, M., Verlicchi, F., Rosa Motta, M., Ricci P., Baccarani, M. \& Tura S. (1991) Pharmacokinetics of high-dose cyclophosphamide for bone marrow transplantation. Haematologica 76: 120-25.

12. Graham, M. I., Shaw, I. C., Souhami, R. L., Sidau, B., Harper, P. G. \& McLean, A. E. M. (1983) Decreased plasma half-life of cyclophosphamide during repeated high-dose administration. Cancer Chemother. Pharmacol. 10: 192-193. 
13. Bagley, C. M. Jr., Bostick, F. W. \& DeVita, V. Jr. (1993) Clinical pharmacology of cyclophosphamide. Cancer Res. 33: 226-233.

14. Grochow, L. B. \& Colvin, M. (1978) Clinical pharmacokinetics of cyclophosphamide. Clin. Pharmacokinet. 4: 380-394.

15. Moore, M. J. (1991) Clinical pharmacokinetics of cyclophosphamide. Clin. Pharmacokinet. 20(3): 194-208.

16. Goldberg, M. A., Antin, J. H., Guinan, E. C. \& Rappeport, J. M. (1986) Cyclophosphamide cardiotoxicity: an analysis of dosing as a risk factor. Blood 68: 1114-1118.

17. Letendre, L., Hoagland, H. C. \& Gertz, M. A. (1992) Hemorrhagic cystitis complicating bone marrow transplantation. Mayo Clin. Proc. 67: 128-130.

18. Hows, J. M., Metha, A., Ward, L., Woods, K., Perez, R., Gordon, M. Y. \& Gordon-Smith, E. C. (1984) Comparison of mesna with forced diuresis to prevent cyclophosphamide induced haemorrhagic cystitis in marrow transplantation: a prospective randomised study. Br. J. Cancer 50: 753-756.

19. Bode, U., Seif, S. M. \& Levine, A. S. (1980) Studies of the antidiuretic effect of cyclophosphamide. Med. Pediatr. Oncol. 8: 295-303.

20. Kaijser, G. P., Korst, A., Beijnen, J. H., Bult A. \& Underberg, W. J. M. (1994) Ifosfamide metabolism and pharmacokinetics (Review). Anticancer Res. 14: 517-532.

21. Antman, K. H., Elias, A. E. \& Ryan, L. (1990) Ifosfamide and mesna: response and toxicity at standard- and high-dose schedules. Semin. Oncol. 17(Suppl 4): 68-73.

22. Elias, A. D., Eder, J. P., Shea, T., Begg, C. B., Frei, E. III \& Antman, K. H. (1990) High-dose ifosfamide with mesna uroprotection: a phase I study. J. Clin. Oncol. 8: 170-178.

23. Brock, N. (1989) Oxazaphosphorine cytostatics: past-present-future. Seventh Cain Memorial Award lecture. Cancer Res. 49: 1-7.

24. Goldin, A. (1982) Ifosfamide in experimental tumor systems. Semin. Oncol. 9: 14-23.

25. Cabanillas, F., Hagemeister, F., Bodey, G. \& Freireich, E. J. (1982) IMVP-16: an effective regimen for patients with lymphoma who have relapsed after initial combination chemotherapy. Blood 60: 693-697.

26. Antman, K., Ryan, L., Elias, A., Sherman, D. \& Grier, H. E. (1989) Response to ifosfamide and mesna: 124 previously treated patients with metastatic or unresectable sarcoma. J. Clin. Oncol. 7: 126-131.

27. Kaijser, G. P., Korst, A., Beijnen, J. H., Bult, A. \& Underberg, W. J. M. (1993) The analysis of ifosfamide and its metabolites (review). Anticancer Res. 13: 1311-1324.

28. Jones, R. B. \& Matthes, S. (1992) Pharmacokinetics. In: Armitage, J. O., Antman, K. H. eds, Highdose cancer therapy. Pharmacology, hematopoietins, stem cells pp. 54-55. Baltimore. Williams and Wilkins.

29. Cvitkovic, E., Droz, J. P., Kattan, J. \& Ghosn, M. (1993) Cisplatin. In: Cvitkovic, E., Droz, J. P., Armand, J. P., Khoury, S. eds. Handbook of Chemotherapy in Clinical Oncology. Jersey. Scientific Communication Internatinal Ltd., pp. 242-246.

30. Patton, T. F., Himmelstein, K. J. \& Belt, R. (1982) Plasma levels and urinary excretion of filterable cisplatinum species following bolus injection and IV infusion of cisdichlorodiammineplatinum(II) in man. Cancer Treat. Rep. 66: 509-516.

31. Reece, P. A., Stafford, I., Russell, J. \& Gill, P. G. (1985) Nonlinear renal clearance of ultrafilterable platinum in patients treated with cis-dichlorodiammineplatinum(II). Cancer Chemother. Pharmacol. 15: 295-299.

32. Dentino, M., Luft, F. C., Nahm Yum, M., Williams, S. D. \& Einhorn, L. H. (1978) Long term effect of cisdiamminechloride platinum (CDDP) on renal function and structure in man. Cancer 41: 1274-1281.

33. Blachly, J. D. \& Hill, J. B. (1981) Renal and electrolyte disturbances associated with cisplatin. Ann. Intern. Med. 95: 628-632.

34. Nichols, G. R., Williams, S. D., Loehrer, P. J., Greco, F. A., Crawford, E. D., Weetlaufer, J., Miller, M. E., Bartolucci, A., Schacter, L. \& Einhorn, L. H. (1991) Randomized study of cisplatin dose intensity in poor-risk germ cell tumors: a southeastern cancer study group and southwest oncology group protocol. J. Clin. Oncol. 9: 1163-1172.

35. Reddel, R. R., Kefford, R. K., Grant, J. M., Coates, A. S., Fox, R. M. \& Tattersall, M. H. N. (1982) Ototoxicity in patients receiving cisplatin: importance of dose and method of drug administration. Cancer Treat. Rep. 66: 19-23. 
36. Canetta, R., Goodlow, J., Smaldone, L., Bragman, K. \& Rozencweig, M. (1990) Pharmacologic characteristics of carboplatin: clinical experience. In: Binn, P. A., Canetta, R., Ozols, R. F., Rozencweig, M., eds. Carboplatin (JM-8), Current Perspectives and Future Directions. Philadelphia: W. B. Saunders Company pp. 19-39.

37. Knox, R. J., Friedlos, F., Lydall, D. A. \& Roberts, J. J. (1988) Mechanism of cytotoxicity of anticancer platinum drugs: evidence that cis-diamminedichloroplatinum(II) and cis-diammine(1,1-cyclobutanedicarboxylato/platinum(II) differ only in the kinetics of their interaction with DNA. Cancer Res. 46: 1972-1979.

38. Calvert, A. H., Harland, S. J., Newell, D. R., Siddik, Z. H., Jones, A. C., McElwain, T. J., Raju, S., Wiltshaw, E., Smith, 1. E., Baker, J. M., Peckham, M. J. \& Harrap, K. R. (1982) Early clinical studies with cis-diammine-1,1-cyclobutane dicarboxylate platinum II. Cancer Chemother. Pharmacol. 9: 140-147.

39. Van Echo, D. A., Egorin, M. J. \& Aisner, J. (1989) The pharmacology of carboplatin. Semin. Oncol. 16(Suppl 5): 1-6.

40. Calvert, A. H., Newell, D. R., Gumbrell, L. A., O'Reilly, S., Burnell, M., Boxall, F. E., Siddik, Z. H., Judson, I. R., Gore, M. E. \& Wiltshaw, E. (1989) Carboplatin dosage: prospective evaluation of a simple formula based on renal function. J. Clin. Oncol. 7: 1748-1756.

41. Shea, T. C., Flaherty, M., Elias, A., Eder, J. P., Antman, K., Begg, C., Schnipper, L., Frei, E. III \& Henner, W. D. (1989) A phase I clinical and pharmacokinetic study of carboplatin and autologous bone marrow support. J. Clin. Oncol. 7: 651-661.

42. Vlasveld, L. T., Beijnen, J. H., Boogerd, W., Ten Bokkel Huinink, W. W. \& Rodenhuis, S. (1990) Complete remission of brain metastases of ovarian cancer following high-dose carboplatin: a case report and pharmacokinetic study. Cancer Chemother. Pharmacol. 25: 382-383.

43. Muggia, F. M. (1989) Overview of carboplatin: replacing, complementing and extending the therapeutic horizons of cisplatin. Semin. Oncol. 16(Suppl 5): 7-13.

44. Gore, M. E., Calvert, A. H. \& Smith, I. E. (1987) High-dose carboplatin in the treatment of lung cancer and mesothelioma: a phase I dose escalation study. Eur. J. Cancer Clin. Oncol. 23: 13911397.

45. Teicher, B. A., Waxman, D. J., Holden, S. A., Wang, Y., Clarke, L., Alvarez Sotomayor, E., Jones, S. M. \& Frie, E. III (1989) Evidence for enzymatic activation and oxygen involvement in cytotoxicity and antitumor activity of N,N',N"-Triethylenethiophosphoramide. Cancer Res. 49: 4996-5001.

46. Cohen, N. A., Egorin, M. J., Snyder, S. W., Ashar, B., Wietharn, B. E., Pan, S., Ross, D. D. \& Hilton, J. (1991) Interaction of $N, N^{\prime}, N^{\prime \prime}-T r i e t h y l e n e t h i o p h o s p h o r a m i d e$ and $N, N^{\prime}, N^{\prime \prime}-$ Triethylenephosphoramide with cellular DNA. Cancer Res. 51: 4360-4366.

47. Egorin, M. J., Snyder, S. W., Pan, S. S. \& Daly, C. (1990) Cellular transport and accumulation of thiotepa. Semin. Oncol. 17(Suppl 3): 7-17.

48. Egorin, M. J., Akman, S. R. \& Gutierrez, P. L. (1984) Plasma pharmacokinetics and tissue distribution of thiotepa in mice. Cancer Treat. Rep. 68: 1265-1268.

49. O'Dwyer, P. J., LaCreta, F., Engstrom, P. F., Peter, R., Tartaglia, L., Cole, D., Litwin, S., DeVito, J., Poplack, D., DeLap, R. J. \& Comis, R. L. (1991) Phase I pharmacokinetic reevaluation of ThioTEPA. Cancer Res. 51: 3171-3176.

50. Jones, R. B. \& Matthes, S. (1992) Pharmacokinetics. In: Armitage, J. O., Antman, K. H., eds High-dose Cancer Therapy. Pharmacology, Hematopoietins, Stem cells. Baltimore: Williams and Wilkins pp. 55-56.

51. Cohen, B. E., Egorin, M. J., Kohlhepp, E. A., Aisner, J. \& Gutierrez, P. L. (1986) Human plasma pharmacokinetics and urinary excretion of thiotepa and its metabolites. Cancer Treat. Rep. 70: 859-864.

52. Wolff, S. N., Herzig, R. H., Fay, J. W., LeMaistre, F., Brown, R. A., Frei-Lahr, D., Stranjord, S., Giannone, L., Coccia, P., Weick, J. L., Rothman, S. A., Krupp, K. R., Lowder, J., Bolwell, B. \& Herzig, G. P. (1990) High-dose N, $N^{\prime}, N^{\prime \prime}$-Triethylenethiophosphoramide (Thiotepa) with autologous bone marrow transplantation: phase I studies. Semin. Oncol. 17 (Suppl 3): 2-6.

53. Damia, G., Tanerna, P. \& D'Incalci, M. (1993) Nitrosureas: Pharmacologic overview. In: Cvitkovic, E., Droz, J. P., Armand, J. P., Khoury, S., eds. Handbook of Chemotherapy in Clinical Oncology. Jersey, Scientific Communication International Ltd. pp. 250-257.

54. MacFarland, J. G., Kirk, M. C. \& Ludlum, D. B. (1990) Mechanism of action of the nitrosureas-IV synthesis of the 2-haloethylnitrosurea-induced DNA cross-link 1-(3-citosinyl), 2(guanyl)ethane. Biochem. Pharm. 39: 33-36. 
55. Pegg, A. E. (1990) Mammalian 06-alkylguanine-DNA-alkyltransferase: regulation and importance in response to alkylating carcinogenetic and therapeutic agents. Cancer Res. 50: 6119-6129.

56. Erickson, L. C., Laurent, G., Sharkey, N. A. \& Kohn, K. W. (1980) DNA cross-linking and monoadduct repair in nitrosurea-treated human tumor cells. Nature 288: 727-729.

57. D'Incalci, M., Citti, L., Taverna, P. \& Catapano, C. V. (1988) Importance of the DNA repair enzyme $\mathrm{O}^{6}$-alkyl guanine alkyltransferase (AT) in cancer chemotherapy. Cancer Treat. Rev. 15: 279-292.

58. Henner, W. D., Peters, W. P., Eder, J. P., Antman, K., Schnipper, L. \& Frei, E. III. (1986) Pharmacokinetics and immediate effects of high-dose carmustine in man. Cancer Treat. Rep. 70: 877880 .

59. Mitchell, E. P. \& Schein, P. S. (1986) Contributions of nitrosureas to cancer treatment. Cancer Treat. Rep. 70: 31-41.

60. Philips, G. L., Fay, J. W., Herzig, G. P., Herzig, R. H., Weiner, R. S., Wolff, S. N., Lazarus, H. M., Karanes, C., Ross, W. E., Kramer, B. S. \& The Southeastern Cancer Study (1983) Intensive 1,3bis(2-chloroethyl)-1-nitrosurea (BCNU), NSC\#4366650 and cryopreserved autologous marrow transplantation for refractory cancer. A phase I-II study. Cancer 52: 1792-1802.

61. Spitzer, G., Dicke, K. A., Verma, D. S., Zander A. \& McCredie K. B. (1979) High-dose BCNU therapy with autologous bone marrow infusion: preliminary observations. Cancer Treat. Rep. 63: 12571264.

62. O'Driscoll, B. R., Hasleton, P. S., Taylor, P. M., Poulter, L. W., Gattamaneni, H. R. \& Woodcock, A. A. (1990) Active lung fibrosis up to 17 years after chemotherapy with carmustine (BCNU) in childhood. N. Engl. J. Med. 323: 378-382.

63. Van der Graff, W. T. A. \& De Vries, E. G. E. (1990) Mitoxantrone: bluebeard for malignancies. AntiCancer Drugs 1: 109-125.

64. Bowden, G. T., Roberts, R., Alberts, D. S., Peng, Y.-M. \& Garcia, D. (1985) Comparative molecular pharmacology in leukemic $L 1210$ cells of the anthracene anticancer drugs mitoxantrone and bisantrene. Cancer Res. 45: 4915-4920.

65. Traganos, F., Evenson, D. P., Staiano-Coico, L., Darzynkiewicz, Z. \& Melamed, M. R. (1980) Action of dihyroxyanthraquinone on cell cycle progression and survival of a variety of cultured mammalian cells. Cancer Res. 40: 671-681.

66. Shenkenberg, T. D. \& von Hoff, D. D. (1986) Mitoxantrone: a new anticancer drug with significant clinical activity. Ann. Intern. Med. 105: 67-81.

67. Tewey, K. M., Rowe, T. C., Yang, L., Halligan, B. D. \& Liu, L. F. (1984) Adriamycin-induced DNA damage is mediated by mammalian DNA topoisomerase II. Science 226: 466-468.

68. Durr, F. E. (1984) Biologic and biochemical effects of mitoxantrone. Semin. Oncol. 11(3 Suppl 1): 3-10.

69. Savaraj, N., Lu, K., Manuel, V. \& Loo, T. L. (1982) Pharmacology of mitoxantrone in cancer patients. Cancer Chemother. Pharmacol. 8: 113-117.

70. Alberts, D. S., Peng, Y.-M., Leigh, S., Davis, T. P. \& Woodward, D. L. (1985) Disposition of mitoxantrone in cancer patients. Cancer Res. 45: 1879-1884.

71. LeMaistre, C. F. \& Herzig, R. (1990) Mitoxantrone: potential for use in intensive therapy. Semin. Oncol. 1(Supp| 3): 43-48.

72. Von Hoff, D. D., Pollard, E., Kuhn, J., Murray, E. \& Coltman, C. A. (1980) Phase I clinical investigation of 1,4-dihydroxy-5,8-bis $\{\{\{2-[2-h y d r o x y e t h y l) a m i n o] e t h y l\} a m i n o\}\}-9,10$-anthracenedione dihydrochloride (NSC 301739), a new anthracenedione. Cancer Res. 40: 1516-1518.

73. Mulder, P. O. M., Sleijfer, D. T., Willemse, P. H. M., De Vries, E. G. E., Uges, D. R. A. \& Mulder, N. H. (1989) High-dose cyclophosphamide or melphalan with escalating doses of mitoxantrone and autologous bone marrow transplantation for refractory solid tumors. Cancer Res. 49: 4654-4658.

74. Cornbleet, M. A., Stuart-Harris, R. C., Smith, I. E., Coleman, R. E., Rubens, R. D., McDonald, M., Mouridsen, H. T., Rainer, H., Van Oosterom, A. \& Smyth, J. F. (1984) Mitoxantrone for the treatment of advanced breast cancer: single agent therapy in previously untreated patients. Eur. J. Cancer Clin. Oncol. 20: 1141-1146.

75. Jones, R. B. \& Matthes, S. (1992) Pharmacokinetics. In: Armitage, J. Q., Antman, K. H., eds. High-dose Cancer Therapy, Pharmacology, Hematopoietins, Stem Cells. Baltimore, Williams and Wilkins. 52-53.

76. Friedman, H. S., Skapek, S. X., Colvin, O. M., Elion, G. B., Blum, M. R., Savina, P. M., Hilton, J., Schold, S. C. Jr, Kurtzberg, J. \& Bigner, D. D. (1988) Melphalan transport, glutathione levels and gluthatione-S-transferase activity in human medulloblastoma. Cancer Res. 48: 5397-5402. 
77. Tranchand, B., Ploin, Y.-D., Minuit, M. P., Sapet, C., Biron, P., Philip, T. \& Ardiet, C. (1989) High-dose melphalan dosage adjustment: possibility of using a test-dose. Cancer Chemother. Pharmacol. 23: 95-100.

78. Tattersall, M. H. N., Jarman, M., Newlands, S., Holyhead, L., Milstead, R. A. V. \& Weinberg, A. (1978) Pharmacokinetics of melphalan following oral or intravenous administration in patients with malignant disease. Eur. J. Cancer 14: 507-513.

79. Cornbleet, M. A., McElwain, T. J., Kumar, P. J., Filshie, J., Selby, P., Carter, R. L., Hedley, D. W., Clark, M. L. \& Milar, J. L. (1983) Treatment of advanced malignant melanoma with high-dose melphalan and autologous bone marrow transplantation. Br. J. Cancer 48: 329-334.

80. Hedley, D. W., Millar, J. L., McElwain, J. T. \& Gordon, M. Y. (1978) Acceleration of bone marrow recovery by pretreatment with cyclophosphamide in patients receiving high-dose melphalan. Lancet 11: 966.

81. Dun, C. R. (1974) The chemical and biological properties of busulphan (myleran). Exp. Hematol. 2: 101-117.

82. Hassan, M., Öberg, G., Ehrsson, H., Ehrnebo, M., Wallin, I., Smedmyr, B., Tötterman, T., Eksborg, S. \& Simonsson, B. (1989) Pharmacokinetics and metabolic studies of high-dose busulphan in adults. Eur. J. Clin. Pharmacol. 36: 525-530.

83. Grochow, L. B., Jones, R. J., Brundrett, R. B., Braine, H. G., Chen, T. L., Saral, R., Santos, G. W. \& Colvin, O. M. (1989) Pharmacokinetics of busulphan: correlation with veno-occlusive disease in patients under-going bone marrow transplantation. Cancer Chemother. Pharmacol. 25: 55-61.

84. Knoester, P. D., Underberg, W. J. M. \& Beijnen, J. H. (1993) Clinical pharmacokinetics and pharmacodynamics of anticancer agents in pediatric patients (review). Anticancer Res. 13: 17951808.

85. Vassal, G. (1993) Alkylating agents: cyclophosphamide, ifosfamide, melphalan, thiotepa, chroambucil, busulfan. In: Cvitkovic, E., Droz, J. P., Armand, J. P., Khoury, S., eds. Handbook of chemotherapy in clinical oncology. Jersey: Scientific Communication International Ltd. 229-230.

86. Clark, P. I. \& Slevin, M. L. (1987) The clinical pharmacology of etoposide and teniposide. Clin. Pharmacokin. 12: 223-252.

87. Postmus, P. E., Holthuis, J. J. M., Haaxma-Reiche, H., Mulder, N. H., Vencken, L. M., van Oort, W. J., Sleyfer, D. T. \& Sluiter, H. J. (1984) Penetration of VP 16-213 into cerebrospinal fluid after highdose intravenous administration. J. Clin. Oncol. 2: 215-220.

88. Postmus, P. E., Mulder, N. H., Sleyfer, D.Th., Meinesz, A. F., Vriesendorp, R. \& De Vries, E. G. E. (1984) High-dose etoposide for refractory malignancies: A phase I study. Cancer Treat. Rep. 68: 1471-1474.

89. Minami, H., Shimokata, K., Saka, H., Saito, H., Ando, Y., Senda, K., Nomura, F. \& Sakai, S. (1993) Phase I clinical and pharmacokinetic study of a 14-day infusion of etoposide in patients with lung cancer. J. Clin. Oncol. 11: 1602-1609.

90. Hudson, M. M., Weinstein, H. J., Donaldson, S. S., Greenwald, C., Kun, L., Tarbell, N. J., Humphrey, W. A., Rupp, C., Marina, N. M., Wilimas, J. \& Link, M. P. (1993) Acute hypersensitivity reactions to etoposide in a VEPA regimen for Hodgkin's disease. J. Clin. Oncol. 11: 1080-1085.

91. Philips, F. S., Schwartz, H. S. \& Sternberg, S. S. (1960) Pharmacology of Mitomycin C: I: toxicity and pathologic effects. Cancer Res. 20: 1354-1361.

92. Crooke, S. T. \& Bradner, W. T. (1976) Mitomycin C: a review. Cancer Treat. Rev. 3: 121-139.

93. Den Hartigh, J., McVie, J. G., van Oort, W. J. \& Pinedo, H. M. (1983) Pharmacokinetics of Mitomycin $C$ in humans. Cancer Res. 43: 5017-5021.

94. Beretta, G., Cova, D. \& Bollina, R. (1993) Mitomycin C In: Cvitkovic, E., Droz, J. P., Armand, J. P., Khoury, S., eds. Handbook of Chemotherapy in Clinical Oncology. Jersey: Scientific Communication International Ltd. 299-303.

95. Tannir, N., Spitzer, G., Dicke, K., Schell, F., DiStefano, A. \& Blumenschein, G. (1984) Phase I-II study of high-dose Mitomycin with autologous bone marrow transplantation in refractory metastatic breast cancer. Cancer Treat. Rep. 68: 805-806.

96. Lazarus, H. M., Gottfried, M. R., Herzig, R. H., Philips, G. L., Weiner, R. S., Sarna, G. P., Fay, J., Wolff, S. N. \& Sudilovsky O. (1982) Veno-occlusive disease of the liver after high-dose mitomycin $\mathrm{C}$ therapy and autologous bone marrow transplantation. Cancer 49: 1789-1795.

97. Sarna, G. P., Champlin, R., Wells, J., Gale, R. G. \& Herzig, G. P. (1982). Phase I study of high-dose mitomycin $C$ with autologous bone marrow support. Cancer Treat. Rep. 66: 277-282.

98. Frei, E. III, Teicher, B. A., Cucchi, C. A., Rosowsky, A., Flatow, J. L., Kelley, M. J. \& Genereux, P. 
(1988) Resistance to alkylating agents: basic studies and therapeutic implications. In: Woolley, P. III, Tew, K., eds. Mechanisms of Drug Resistance in Neoplastic Cells. New York: Academic Press pp. 69-86.

99. Frei, E. III, Teicher, B. A., Holden, S. A., Cathcart, K. N. S. \& Wang, Y. (1988) Preclinical studies and clinical correlation of the effect of alkylating dose. Cancer Res. 48: 6417-6423.

100. Teicher, B. A., Holden, S. A., Cucchi, C. A., Cathcart, K. N. S., Korbut, T. T., Flatow, J. L. \& Frei, E. III. (1988) Combination of $N, N^{\prime}, N^{\prime \prime}-T$ riethylenethiophosphoramide and cyclophosphamide in vitro and in vivo. Cancer Res. 48: 94-100.

101. Schabel, F. N. Jr, Trader, N. W., Laster, W. R. Jr, Wheeler, G. P. \& Witt, M. H. (1978) Patterns of resistance and therapeutic synergism among alkylating agents. Antibiot. Chemother. 23: 200215.

102. Frei, E. III. (1992) Pharmacologic strategies for high-dose chemotherapy. In: Armitage, J. O., Antman, K. H., eds. High-dose Cancer Therapy. Pharmacology, Hematopoietins, Stem Cells. Baltimore. Williams and Wilkins 3-13.

103. Williams, S. F., Bitran, J. D., Kaminer, L., Westbrook, C., Jacobs, R., Ashenhurst, J., Robin, E., Purl, S., Beshorner, J., Schroeder, C. \& Golomb, H. M. (1987) A phase I-II study of bialkylator chemotherapy, high-dose thiotepa, and cyclophosphamide with autologous bone marrow reinfusion in patients with advanced cancer. J. Clin. Oncol. 5: 260-265.

104. Eder, J. P., Antman, K., Elias, A., Shea, T. C., Teicher, B., Henner, W. D., Schryber, S. M., Holden, S., Finberg, R., Chritchlow, J., Flaherty, M., Mick, R., Schnipper, L. E. \& Frei, E. III. (1988) Cyclophosphamide and thiotepa with autologous bone marrow transplantation in patients with solid tumors. J. Natl. Cancer Inst. 80: 1221-1226.

105. Williams, S. F., Mick, R., Desser, R., Golick, J., Beschorner, J. \& Bitran, J. D. (1989) High-dose consolidation therapy with autologous stem cell rescue in stage IV breast cancer. J. Clin. Oncol. 7: $1824-1830$.

106. Kennedy, M. J., Beveridge, R. A., Rowley, S. D., Gordon, G. B., Abeloff, M. D. \& Davidson, N. E. (1991) High-dose chemotherapy with reinfusion of purged autologous bone marrow following dose-intense induction as initial therapy for metastatic breast cancer. J. Natl. Cancer Inst. 83: 920-926.

107. Teicher, B. A., Holden, S. A., Jones, S. M., Eder, J. P. \& Herman, T. N. (1989) Influence of scheduling on two-drug combinations of alkylating agents in vivo. Cancer Chemother. Pharmacol. 25: $161-166$.

108. Antman, K., Eder, J. P., Elias, A., Ayash, L., Shea, T. C., Weissman, L., Critchlow, J., Schryber, S. M., Begg, C., Teicher, B. A., Schnipper, L. E. \& Frei, E. III. (1990) High-dose thiotepa alone and in combination regimens with bone marrow support. Semin Oncol. 17 (Suppl 3): 33-38.

109. Eder, J. P., Elias, A., Shea, T. C., Schryber, S. M., Teicher, B. A., Hunt, M., Burke, J., Siegel, R., Schnipper, L. E., Frei, E. III. \& Antman K. (1990) A phase I-Il study of cyclophosphamide, thiotepa and carboplatin with autologous bone marrow transplantation in solid tumor patients. J. Clin. Oncol. 8: 1239-1245.

110. Antman, K., Ayash, L., Elias, A., Wheeler, C., Hunt, M., Eder, J. P., Teicher, B. A., Critchlow, J., Bibbo, J., Schnipper, L. E. \& Frei, E. III. (1992) A phase II study of high-dose cyclophosphamide, thiotepa and carboplatin with autologous marrow support in women with measurable advanced breast cancer responding to standard dose therapy. J. Clin. Oncol. 10: 102-110.

111. Ayash, L. J., Elias, A., Wheeler, C., Reich, E., Schwartz, G., Mazanet, R., Tepler, I., Warren, D., Lynch, C., Gonin, R., Schnipper, L., Frei, E. III. \& Antman, K. (1994) Double dose-intensive chemotherapy with autologous marrow and peripheral-blood progenitor-cell support for metastatic breast cancer: a feasibility study. J. Clin. Oncol. 12: 37-44.

112. Rodenhuis, S., Baars, J. W., Schornagel, J. H., Vlasveld, L. T., Mandjes, I., Pinedo, H. M. \& Richel, D. J. (1992) Feasibility and toxicity study of a high-dose chemotherapy regimen for autotransplantation incorporating carboplatin, thiotepa and cyclophosphamide, Ann. Oncol. 3: 855-860.

113. Van der Wall, E., Nooijen, W. J., Baars, J. W., Holtkamp, M. J., Schornagel, J. H., Richel, D. J., Rutgers, E. J. T., Slaper-Cortenbach, I. C. M., Van der Schoot, C. E. \& Rodenhuis, S. (1995) Highdose carboplatin, thiotepa and cyclophosphamide (CTC) with peripheral blood stem cell support in the adjuvant therapy of high-risk breast cancer: a practical approach. Br. J. Cancer, in press.

114. Rodenhuis, S., Van der Wall, E., Ten Bokkel Huinink, W. W., Schornagel, J. H., Richel, D. J. \& Vlasveld, L. T. (1995) Pilot study of a high-dose carboplatin-based salvage strategy for relapsing or refractory germ cell cancer. Cancer Invest. in press. 
115. Ghalie, R., Richman, C. M., Adler, S. S., Cobleigh, M. A., Korenblitt, A. D., Manson, S. D., McLeod, B. C., Taylor, S. G. IV, Valentino, L. A., Wolter, J. \& Kaizer, H. (1994) Treatment of metastatic breast cancer with a split-course high-dose chemotherapy regimen and autologous bone marrow transplantation. J. Clin. Oncol. 12: 342-346.

116. Peters, W. P., Eder, J. P., Henner, W. D., Schryber, S., Wilmore, D., Finberg, R., Schoenfeld, D., Bast, R., Gargone, B., Antman, K., Anderson, J., Anderson, K., Kruskall, M. S., Schnipper, L. \& Frei, E. III. (1988) High-dose combination alkylating agents with autologous bone marrow support: a phase I trial. J. Clin. Oncol. 4: 646-654.

117. Todd, N. W., Peters, W. P., Ost, A. H., Roggli, V. L. \& Piantadosi, C. A. (1993) Pulmonary drug toxicity in patients with primary breast cancer treated with high-dose combination chemotherapy and autologous bone marrow transplantation. Am. Rev. Respir. Dis. 147: 1264-1270.

118. Eder, J. P., Antman, K., Peters, W., Henner, W. D., Elias, A., Shea, T., Schryber, S., Andersen, J., Come, S., Schnipper, L. \& Frei, E. III. (1986). High-dose combination alkylating agent chemotherapy with autologous bone marrow support for metastatic breast cancer. J. Clin. Oncol. 4: 1592-1597.

119. Peters, W. P., Shpall, E. J., Jones, R. B., Olsen, G. A., Bast, R. C., Gockerman, J. P. \& Moore, J. O. (1988) High-dose combination of alkylating agents with bone marrow support as initial treatment for metastatic breast cancer. J. Clin. Oncol. 6: 1368-1376.

120. Slease, R. B., Benear, J. B., Selby, G. B., Reitz, C. L., Hughes, W. L., Watkins, C. L. \& Epstein, R. B. (1988) High-dose combination alkylating agent therapy with autologous bone marrow rescue for refractory solid tumors. J. Clin. Oncol. 6: 1314-1320.

121. Jones, R. B., Shpall, E. J., Ross, M., Coniglio, D., Affronti, M. L. \& Peters, W. P. (1990) High-dose carboplatin, cyclophosphamide and BCNU with autologous bone marrow support: excessive hepatic toxicity. Cancer Chemother. Pharmacol. 26: 155-156.

122. Postmus, P. E., De Vries, E. G. E., De Vreis-Hospers, H. G., Vriesendorp, R., Van Imhoff, G. W., Holthuis, J. J. M., Smit Siebenga, C. Th., Sleijffer, D. Th. \& Mulder, N. H. (1984) Cyclophosphamide and VP 16-213 with autologous bone marrow transplantation. A dose escalation study. Eur. J. Cancer Clin. Oncol. 20: 777-782.

123. Humblet, Y., Symann, M., Bosly, A., Delaunois, L., Francis, C., Machiels, J., Beauduin, M., Doyen, C., Weynants, P., Longueville, J. \& Prignot, J. (1987) Late intensification chemotherapy with autologous bone marrow transplantation in selected small-cell carcinoma of the lung: a randomized study. J. Clin. Oncol. 5: 1864-1873.

124. Shea, T. C., Storniolo, A. M., Mason, J. R., Newton, B., Mullen M., Taetle, R. \& Green, M. R. (1992) A dose-escalation study of carboplatin/cyclophosphamide/etoposide along with autologous bone marrow or peripheral blood stem cell rescue. Semin. Oncol. 19 (Suppl 2): 139-144.

125. Motzer, R. J., Gulati, S. C., Tong, W. P., Menendez-Botet, C., Lyn, P., Mazumdar, M., Vlamis, V., Lin, S. \& Bosl, G. (1993) Phase I trial with pharmacokinetic analysis of high-dose carboplatin, etoposide, and cyclophosphamide with autologous bone marrow transplantation in patients with refractory germ cell tumors. Cancer Res. 53: 3730-3735.

126. Nichols, C. R., Tricot, G., Williams, S. D., Van Besien, K., Loehrer, P. J., Roth, B. J., Akard, L., Hoffman, R., Goulet, R., Wolff, S. N., Giannone, L., Greer, J., Einhorn, L. H. \& Jansen, J. (1989) Dose-intensive chemotherapy in refractory germ cell cancer-a phase $1 / / 1$ trial of high-dose carboplatin and etoposide with autologous bone marrow transplantation. J. Clin. Oncol. 7: 932-939.

127. Nicols, C. R., Andersen, J., Lazarus, H. M., Fisher, H., Greer, J., Stadtmauer, E. A., Loehrer, P. J. \& Trump, D. L. (1992) High-dose carboplatin and etoposide with autologous bone marrow transplantation in refractory germ cell cancer: an Eastern Cooperative Oncology Group Protocol. J. Clin. Oncol. 10: 558-563.

128. Broun, E. R., Nichols, C. R., Einhorn, L. H. \& Tricot, G. L. K. (1991) Salvage therapy with high-dose chemotherapy and autologous bone marrow support in the treatment of primary nonseminomatous mediastinal germ cell tumors. Cancer 68: 1513-1515.

129. Broun, E. R., Nichols, C. R., Tricot, G., Loehrer, P. J., Williams, S. D. \& Einhorn, L. H. (1991) Highdose carboplatin/NP-16 plus ifosfamide with autologous bone marrow support in the treatment of refractory germ cell tumors. Bone Marrow Transplant 7: 53-56.

130. Rosti, G., Albertazzi, L., Salvioni, R., Pizzocaro, G., Cetto, G. L., Bassetto, M. A. \& Marangolo, M. (1992) High-dose chemotherapy supported with autologous bone marrow transplantation (ABMT) in germ cell tumors: a phase two study. Ann. Oncol. 3: 809-812.

131. Santos, G. W. (1993) The development of busulfan/cyclophosphamide preparative regimens. Semin. Oncol. 20: 12-16. 
132. Klumpp, T. R., Mangan, K. F., Glenn, L. D. \& Macdonald, J. S. (1993) Phase II pilot study of highdose busulfan and $\mathrm{CY}$ followed by autologous BM or peripheral blood stem cell transplantation in patients with advanced chemosensitive breast cancer. Bone Marrow Transplant 11: 337-339.

133. De Vries, E. G. E., Rodenhuis, S., Schouten, H. C., Hupperets, P. S. G. J., Blijham, G. H., Bontebal, M., Rodenburg, C. J. \& Mulder, N. H. (1994) Phase II study of intensive chemotherapy with autologous bone marrow transplantation in patients in complete remission of disseminated breast cancer. Proc. Am. Soc. Clin. Oncol. 14: 87 (abstr 151).

134. Lewkow, L. M., Hooker, J. L. \& Movahed, A. (1992) Cardiac complications of intensive dose mitoxantrone and cyclophosphamide with autologous bone marrow transplantation in metastatic breast cancer. Int. J. Cardiol. 34: 273-276.

135. Bowers, C., Adkins, D., Dunphy, F., Harrison, B., LeMaistre, C. F. \& Spitzer, G. (1993) Dose escalation of mitoxantrone given with thiotepa and autologous bone marrow transplantation for metastatic breast cancer. Bone Marrow Transplant 12: 525-530.

136. Broun, E. R., Sledge, G. W., Einhorn, L. H. \& Tricot, G. J. K. (1993) High-dose carboplatin and mitoxantrone with autologous bone marrow support in the treatment of advanced breast cancer. Am. J. Clin. Oncol. (CCT) 16(1): 9-13. 